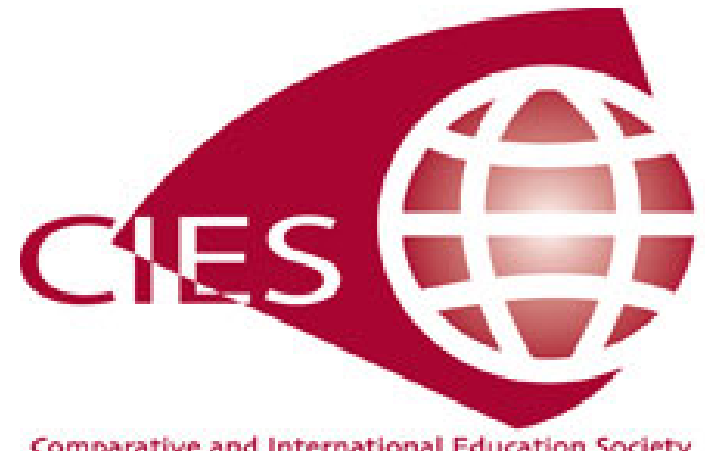

Transnational Advocacy, Global Civil Society? Emerging Evidence from the Field of Education Author(s): Karen Mundy and Lynn Murphy

Reviewed work(s):

Source: Comparative Education Review, Vol. 45, No. 1 (February 2001), pp. 85-126

Published by: The University of Chicago Press on behalf of the Comparative and International Education

Society

Stable URL: http://www.jstor.org/stable/10.1086/447646

Accessed: 15/12/2011 14:17

Your use of the JSTOR archive indicates your acceptance of the Terms \& Conditions of Use, available at http://www.jstor.org/page/info/about/policies/terms.jsp

JSTOR is a not-for-profit service that helps scholars, researchers, and students discover, use, and build upon a wide range of content in a trusted digital archive. We use information technology and tools to increase productivity and facilitate new forms of scholarship. For more information about JSTOR, please contact support@jstor.org.

The University of Chicago Press and Comparative and International Education Society are collaborating with JSTOR to digitize, preserve and extend access to Comparative Education Review. 


\title{
Transnational Advocacy, Global Civil Society? Emerging Evidence from the Field of Education
}

\author{
KAREN MUNDY AND LYNN MURPHY
}

\begin{abstract}
It is now possible to speak of an international system of influence powerful enough to bind up the educational destinies of the world's peoples. If such a network of global influence limits the discretion of peoples to shape their own educational destinies and imposes its own solution to the materialmoral dilemma facing educational policy, then it is worthy of investigation.

(Phillip Jones, World Bank Financing of Education)
\end{abstract}

The argument that a widening and increasingly influential "international architecture" has developed in the field of education has been made with relative frequency in recent years as interest in and research on international organizations in the field of education have grown. ${ }^{1}$ As reflected in the above quotation from Phillip Jones's masterful study of the World Bank, much of this work has tended to focus on (and question) the hegemonic influence of formal intergovernmental organizations, both as these directly influence domestic educational policies and as they construct a global interpretation of, and set of responses to, worldwide educational "needs."

At the same time, a mounting literature on globalization and the changing nature of international relations has provided convincing evidence that an increasingly strong and complex array of international nongovernmental actors and new nongovernmental organizational (NGO) forms is emerging. Described variously as "transnational advocacy networks" (TANs) or "transnational social movements" (TSMs), these new organizational forms bring together a wide array of nongovernmental organizations, citizens associations, and trade unions in forms of activism that target global-level institu-

This research was supported by the National Academy of Education and the Spencer Foundation, through a postdoctoral fellowship awarded to Karen Mundy, 1998-99.

${ }^{1}$ Miriam Henry, Bob Lingard, Fazal Rizvi, and Sandra Taylor, The OECD, Globalization and Education Policy (Oxford: Pergamon, 2000); Phillip Jones, "Unesco and the Politics of Global Literacy," Comparative Education Review 34, no. 1 (1988): 41-60, World Bank Financing of Education (New York: Routledge, 1992), and International Policies for Third World Education: Unesco, Literacy and Development (New York: Routledge, 1988); Connie McNeely and Yun-Kyung Cha, "Worldwide Educational Convergence through International Organizations: Avenues for Research," Educational Policy Analysis Archives 2, no. 14 (1994), available at http://epaa.asu.edu/epaa/v2n14.html; Karen Mundy, "Educational Multilateralism and World (Dis) Order," Comparative Education Review 42, no. 4 (1998): 448-78, and "Unesco and the Limits of the Possible," International Journal of Educational Development 19, no. 1 (1999): 27-52; Francisco Ramirez and John Boli, "Global Patterns of Educational Institutionalization," in Institutional Structure: Constituting State, Society and the Individual, ed. George Thomas, John W. Meyer, Francisco O. Ramirez, and John Boli (Beverly Hills, Calif.: Sage, 1987), pp. 150-72.

Comparative Education Review, vol. 45, no. 1 .

(C) 2001 by the Comparative and International Education Society. All rights reserved.

0010/4086/2001/4501-0004\$02.00 
tions and issues while they attempt to use global-level visibility to level changes at the national level. These TANs or TSMs are the focus of a thriving and often ethically inspired literature that sets out to study the origins, strength, influence, and long-term implications of their activities on the broader development of a world-level political system. ${ }^{2}$ They are frequently portrayed as the building blocks of a prototypical "global civil society," with the power to influence, and perhaps democratize, the structure of world politics, both through their increasing influence within existing international institutions and through their capacity to use this influence to leverage change in individual nation-states.

This article brings together these two lines of research: one concerned with the evolution of an international system of influence in education, the other with the broader possibility of a more democratic form of global governance. Our focus is on the emergence and evolution of nongovernmental actors and organizational forms engaged in transnational advocacy in the field of education. ${ }^{3}$ We ask whether or not there has been a deep, qualitative change in the involvement of nongovernmental actors in the field of international educational cooperation over the past decade, one parallel to trends described in the burgeoning literature on transnational advocacy networks, international nongovernmental organizations, and global civil society. The answer to this question, as we hope to show, is yes. There are clear signs of a new and qualitatively different wave of transnational nongovernmental advocacy initiatives in education, especially around the idea of "education for all." This can be seen by comparing nongovernmental participation in international educational forums over time, by looking more closely at the recent genesis of an NGO-led "Global Campaign for Education," and by analyzing nongovernmental activism at the most recent international meeting on education, the World Education Forum (WEF), which was held in April 2000 in Dakar, Senegal, as a 10-year follow-up to the Jomtien World Conference on Education for All.

${ }^{2}$ John Boli and George Thomas, eds., Constructing World Culture: International Nongovernmental Organizations since 1875 (Stanford, Calif.: Stanford University Press, 1999); Margaret Keck and Kathryn Sikkink, Activists beyond Borders (Ithaca, N.Y.: Cornell University Press, 1998); Ronnie Lipschutz, "Reconstructing World Politics: The Emergence of Global Civil Society," in International Society after the Cold War, ed. Rich Fawn and Jeremy Larkins (New York: St. Martin's Press, 1996), pp. 101-31; James Rosenau, Along the Domestic-Foreign Frontier (New York: Cambridge University Press, 1997); Jackie Smith, ed., Transnational Social Movements, Solidarity beyond the State (Syracuse, N.Y.: Syracuse University Press, 1997).

${ }^{3}$ It is not our intention to review the literature on nongovernmental organizations in domestic educational arenas, although this has been a thriving theme of debate in recent years in the field of comparative education. See, e.g., David Archer, "The Changing Roles of Non-governmental Organizations in the Field of Education," International Journal of Educational Development 14, no. 3 (1994): 223-32; and also articles by Robert Arnove and Rachel Christina ("NGO-State Relations: An Argument in Favor of the State and Complementarity Efforts"), Steve Klees ("NGO's: A Progressive Force or Neoliberal Tool"), and Nelly Stromquist ("NGOs in a New Paradym of Civil Society"), all in Current Issues in Comparative Education 1, no. 1 (November 1998), an electronic journal (http://www.tc.columbia.edu/ academic/ice/, March 10, 1999). 
Our goals in this article are twofold. First, we present an exploratory account of the trends suggestive of a new kind of nongovernmental activism in the field of education, drawing on over 2 dozen interviews and documentary data; and second, we set out an analytical framework for assessing the significance of that activism, drawing on concepts from research on new social movements and from current theoretical debates about global civil society. Here we hope to raise larger questions about the future of international cooperation in education and the potential for new and more democratic structures of global governance.

\section{Transnational Advocacy Networks and Global Civil Society: Toward a Conceptual Framework}

The end of the Cold War; rising evidence of global economic, social, and cultural integration; and the increasingly visible activities of networks of transnational social movements focused on such issues as the environment, women's rights, human rights, Third-World debt, and globalization have given impetus to a renewed interest in the influence of nonstate actors in the world system over the past decade. From a purely empirical stance, studying the growing complexity and volume of international relations among nonstate actors (and between nonstate actors and states) and characterizing the way these interact to structure a single, world-level political system has become a major challenge to the entire field of international relations. ${ }^{4}$ At the same time, an ethical or normative question lies at the core of a growing interest in the capacity of nongovernmental networks to influence world order. Whether framed by liberal or critical traditions of political thought, the key question here is, To what extent can networks of nongovernmental actors influence the development of a more just world order that is both equitable and representative?

Collective action among nongovernmental actors at the international level is, of course, not an entirely new phenomenon. International links between nongovernmental organizations, citizens groups, expert communities, and trade unions began to thicken in the middle of the nineteenth century, often stimulated by the desire to share information and offer mutual support and solidarity for national reform movements. Once an international link was made, many of these organizations played a key role in the establishment of formal intergovernmental agreements and institutionskey examples include the antislavery movement of the nineteenth century, the child survival movement of the early twentieth century, and the work of the international labor movement in the formation of the International

${ }^{4}$ James Nye and Robert Keohane, Power and Interdependence: World Politics in Transition (Boston: Little Brown, 1977); James Rosenau, "Governance, Order and Change in World Politics," in Governance without Government, ed. James N. Rosenau and Earnest O. Czempiel (New York: Cambridge University Press, 1992), pp. 1-291, and Along the Domestic-Foreign Frontier. 
Labor Organization and its conventions. ${ }^{5}$ Yet because international nongovernmental organizations were largely dependent on resources provided by nation-states and because they were often marginalized in the decisionmaking processes of international organizations during the Cold War era, there was a widely shared sense that these organizations were not significant or sufficiently autonomous players in international politics. Until quite recently, political scientists have viewed transnational nongovernmental actors as marginal to state-based power politics.

Today that sense of insignificance has evaporated, for two broad reasons. The first set of factors influencing the new salience of international nongovernmental actors is largely contextual. This century has seen the steady institutionalization of new global structures of governance and political power that have "transformed world politics into a global politics of agenda setting, coalition building and multilateral regulation." ${ }^{6}$ Moreover, recent intensification of processes of economic, political, and cultural globalization raises questions for each about the appropriate locus of political decision making in an increasingly complex, interdependent world. The problem is of a world order in which decisions made by centers of power (states, multilateral institutions, and, increasingly, international corporations and financial capital) have repercussions beyond national boundaries, while forms of democratic participation and societal compromise remain territorially grounded in increasingly hollowed-out welfare states. In this context, it can be argued, the rise of new technologies, increasing pressure on nongovernmental actors to fill in the social service vacuum left by the state, and the historical accumulation of models and spaces for transnational collective action have combined to create a unique "opportunity" for the development of new effective forms of transnational nongovernmental contestation.

Second, in simple empirical terms, "the number, size, professionalism, and the speed, density and complexity of international linkages among [international nongovernmental organizations] has grown dramatically in the last three decades." 7 This growth is especially marked around the issues of women's rights, the environment, peace, development, and human rights, where a variety of nonstate actors have come together as advocates of major social and political change in what scholars have described variously as "trans-

\footnotetext{
${ }^{5}$ For historical case studies, see Boli and Thomas; Lyman Cromwell White, International Nongovernmental Organizations: Their Purposes, Methods and Accomplishments (New Brunswick, N.J.: Rutgers University Press, 1951); Martha Finnemore, National Interests in International Society (Ithaca, N.Y.: Cornell University Press, 1996); and Smith.

${ }^{6}$ David Held and Anthony McGrew, Global Transformations: Politics, Economics and Culture (Stanford, Calif.: Stanford University Press, 1999), quote on p. 431. See also Manuel Castells, The Power of Identity, The Information Age: Economy, Society and Culture, vol. 2 (Oxford: Blackwell, 1997); Rosenau, "Governance, Order and Change in World Politics."

${ }^{7}$ Keck and Sikkink, p. 11. Also, strong empirical evidence of the overall growth of international nongovernmental actors is provided by Boli and Thomas; also see Smith.
} 
national advocacy networks," "principled issue networks," and "transnational social movements." These networks are increasingly visible-one need only think, for example, of the nongovernmental activism at the United Nations conferences of the $1990 \mathrm{~s}^{;}{ }^{8}$ the Jubilee 2000 campaign against ThirdWorld debt; ${ }^{9}$ the international campaign against the Multilateral Agreement on Investment; the antilandmine campaign; ${ }^{10}$ and the broad coalition movement mobilized for the fall 1999 meetings of the World Trade Organization (WTO) and the spring 2000 meetings of the World Bank and the International Monetary Fund. ${ }^{11}$

The expansion and visibility of such transnational nongovernmental advocacy networks have raised two key questions for international relations scholars. First, how do these networks work? Second, are they effective, autonomous actors in world politics? On the first point, there is broad consensus: working without significant financial or electoral resources, these new collective actors use telecommunications and transportation technologies to build networks and generate international public interest in an issue. They develop highly publicized campaigns that target international organizations or intergovernmental regimes, and they link domestic and international groups in collective protests against both governments and international organizational policies in what Margaret Keck and Kathryn Sikkink describe as a common "boomerang" strategy designed to provide domestic movements greater leverage against their home governments. These networks have had

\footnotetext{
${ }^{8}$ Anne Marie Clark, Elisabeth J. Friedman, and Kathryn Hochsteltler, "The Sovereign Limits of Global Civil Society: A Comparison of NGO Participation in UN World Conferences on the Environment, Human Rights, and Women," World Politics 51, no. 1 (October 1998): 1-35; Alison Van Rooy, "The Frontiers of Influence: NGO Lobbying at the 1974 World Food Conference, the 1992 Earth Summit and Beyond," World Development 25, no. 1 (1997): 93-114; L. Gordenker and T. G. Weiss, "NGO Participation in the International Policy Process," Third World Quarterly 16, no. 3 (1995): 543-613.

${ }^{9}$ Jubilee 2000 is a "worldwide movement to cancel the crushing international debt of impoverished countries by the new millennium" (http://www.oneworld.org/jubilee2000). The campaign is led by a coalition of church-based and development organizations and has achieved significant prominence through worldwide lobbying of national governments and a direct action campaign that utilizes the formation of "human chains" around the sites of key intergovernmental conferences, most recently at the G7 interministerial meetings in June 1999. See John Mihevc, "Jubilee 2000: Starting from Scratch," New Internationalist, no. 312 (May 1999): 22-24.

${ }^{10}$ Richard Price, "Reversing the Gun Sights: Transnational Civil Society Targets Land Mines," International Organization 52, no. 3 (Summer 1998): 613-44.

${ }^{11}$ Cecilia Lynch, "Social Movements and the Problem of Globalization," Alternatives 23 (1998): 149-73. For extensive coverage of World Trade Organization events, see Seattle Times (November 26December 3, 1999); and World Bank, Development News (November 26-30, 1999) (http://www.devnews@ worldbank.org). For protests in Washington, D.C., see World Bank, Development News (April 17, 2000); or "IMF and World Bank Carry on Meeting Even with Protests," Washington Post (April 17, 2000), p. A07. Several web sites also hosted extensive coverage of the protests and the coalitions that have formed to monitor them, such as A16 (http://www.a16.org) and WTOwatch (http://www.wtowatch.org). The A16 (or August 16) web site is run by a consortium of antiglobalization NGOs and citizen organizations under the title "Mobilization for Global Justice." The WTOwatch is a web site devoted to news and analysis on the World Trade Organization, trade, and sustainable development. It is operated by the Institute of Agriculture and Trade Policy, a nonprofit research organization based in Minneapolis that was formed in 1986.
} 
a cumulative impact: they increasingly interact, use similar strategies and repertoires for action, and mobilize around overlapping collective action frames. ${ }^{12}$

Less agreement exists, however, about the long-term influence of these nongovernmental networks on world politics. Most scholars agree that their greatest impact to date has been "at the level of agenda setting, the spreading norms and changes in intergovernmental and governmental discourse." 13 But very different assessments have been offered of their success in holding nations and international organizations accountable to new agendas, or in achieving the deeper democratization of international organizations and intergovernmental forums, which is so often a key part of their agenda. Thus, while many scholars have gone so far as to describe these new nongovernmental networks as the harbingers of "global civil society" (which they conceptualize as a redemptive, semiautonomous political space in which popular organizations come together to create and participate in institutions of global governance), others raise serious questions about the longterm capacities and representativeness of the new advocacy movements. They prefer to think of them as uneven transnational (rather than global) networks whose development into an effective global civil society needs to be empirically studied rather than naively assumed. ${ }^{14}$

Our framework for researching and thinking about transnational advocacy in the field of education draws extensively from this broader literature and its debates. The first stage of our research has been an effort to describe and explain the appearance of new forms and types of collective action among nongovernmental actors in the field of education. In what follows,

\footnotetext{
${ }^{12}$ Keck and Sikkink (n. 2 above), p. 12; Smith (n. 2 above); Price; Lipschutz (n. 2 above); Clark, Friedman, and Hochstelter "Sovereign Limits of Global Civil Society"; Boli and Thomas (n. 2 above); Lynch. For an overarching assessment of the normative potential held by such organizations, see Martha Finnemore and Kathryn Sikkink, "International Norm Dynamics and Political Change," International Organization 52, no. 4 (autumn 1998): 887-917.

${ }^{13}$ Keck and Sikkink, p. 12.

${ }^{14}$ Clark, Friedman, and Hochsteltler, "Sovereign Limits of Global Civil Society"; Lipschutz; Mustapha Pasha and David Blaney, "Elusive Paradise: The Promise and Peril of Global Civil Society," Alternatives 23 (1998): 417-50; Diane Otto, "Nongovernmental Organizations in the United Nations System: The Emerging Role of International Civil Society" Human Rights Quarterly 18, no. 1 (1996): 107-14; W. Andy Knight, "Engineering Space in Global Governance: The Emergence of Civil Society in Evolving 'New' Multilateralism," in Future Multilateralism, ed. Michael G. Schechter (New York: St. Martin's Press, 1999), pp. 255-91; M. Smouts, "Multilateralism from Below: a Prerequisite for Global Governance," in Schechter, ed., pp. 292-311; Lisa Jordan and Peter van Tuijl, "Political Responsibility in NGO Advocacy: Exploring Emerging Shapes of Global Democracy," Novib web site, April 1998 (http >//www.oneworld.org/ euforic/novib/novib1.htm, July 12, 1999); Michael Edwards, David Hulme, and T. Wallace, "NGOs in a Global Future: Marrying Local Delivery to World Wide Leverage" (Ford Foundation, 1999, mimeographed); Blair Rutherford, "Civil (Dis) Obedience and Social Development in the New Policy Agenda: Research Priorities for Analyzing the Role of Civil Society Organizations in Social Policy Reform, with Particular Attention to Sub-Saharan Africa and Latin America," 1998 (http://www.idrc.ca/socdev/pub/ documents/civilsociety.html, April 8, 1999), International Development Research Center; Alison Van Rooy, Civil Society and the Aid Industry: The Politics and Promise (London: Earthscan, 1998). For an official account of the significance of "global civil society," see the United Nations Commission on Global Governance, Our Global Neighborhood (New York: Oxford University Press, 1995).
} 
we begin with a historical overview of nongovernmental networks in the field of education. Then we borrow from recent research on new social movements and transnational advocacy to organize a case study of the key organizations involved in the genesis of a recently launched nongovernmental advocacy initiative, the Global Campaign for Education. ${ }^{15}$ Here we look at two key processes. First, we build on Marie-Claude Smout's observation that international nongovernmental organizations (INGOs) derive "their legitimacy from their ability to make demands in terms of collective needs . . . [and] from their innovative capacity to suggest ways to meet these needs" by focusing on the "mobilizing frames" or ways in which global educational problems and their solutions are talked about and used to legitimate and motivate collective action among nongovernmental actors. ${ }^{16}$ Second, we look at the "repertoires of contention" that each advocacy initiative utilizes, defined here as the set of practices and strategies being developed by international nongovernmental actors to leverage educational change. ${ }^{17}$

The second step in our framework involves addressing the "so what" question that underlies recent debates about transnational advocacy and global civil society. To do so, we follow in the footsteps of international relations scholars who have transposed the concept of civil society from its more common usage in political theories of the nation-state. Like them, we recognize that the absence of a supranational state makes the transposition of theories of "civil society" problematic, but we think that the current world context-characterized by powerful international institutions and mounting popular recognition of the need for greater international oversight of the world economy-makes it imperative that we consider the potential emergence of global civil society and find ways of studying it empirically.

Two theoretical traditions have been used by scholars in the field of international relations to generate a loose evaluative template for thinking about transnational advocacy networks and the extent to which they approximate global civil society. The liberal tradition emphasizes the importance of a pluralistic political order; it values civil society in two ways, both as a

${ }^{15}$ See John McCarthy, "The Globalization of Social Movement Theory," in Smith, ed., pp. 243-57; Dieter Rucht, "The Transnationalization of Social Movements: Trends, Causes, Problems," in Social Movements in a Globalizing World, ed. Hanspeter Kriesi, Dieter Rucht, and Donatella della Porta (New York: St. Martin's Press, 1999), pp. 206-22; and Sydney Tarrow, "Transnational Contention," in Power in Movement: Social Movements and Contentious Politics, ed. Sidney Tarrow (Cambridge: Cambridge University Press, 1998), pp. 176-95.

${ }^{16}$ See Smouts, p. 304. The idea of "framing" is drawn from David Snow and Robert Benford, "Master Frames and Cycles of Protest," in Frontiers of Social Movement Theory, ed. Aldon Morres and Carol Mueller (New Haven, Conn.: Yale University Press, 1992), pp. 133-55. Smith (n. 2 above) transposes this to the study of transnational social movements and describes framing as the development of interpretive frames that "process political information, interpreting certain conditions as problems in need of attention and conveying the need and potential efficacy of collective attempts to address the problem" (p. 73). See also, Clark, Friedman, and Hochsteltler, "Sovereign Limits of Global Civil Society."

${ }^{17}$ See Sidney Tarrow, "Cycles of Collective Action: Between Moments of Madness and Repertoires of Contention," in his Repertoires and Cycles of Collective Action (Durham, N.C.: Duke University Press 1995), p. 91. 
check on the excesses of the state and governmental bureaucracy and as the arena responsible for producing the degree of consensus and civility necessary for the functioning of formal, representative democracy and a pluralist society. Gramscian and other critical traditions are more interested in understanding the opportunities for counterhegemony and contention that exist within civil society. Here it is assumed that civil society is the space in which consent to a capitalist system is culturally constructed by a variety of actors (including the state) and, therefore, that it is also a key location for its opposition. $^{18}$

Overall, theories of international civil society drawn from the literature on domestic politics "envision a dense exchange among individuals, groups, and organizations in the public sphere, separate from state dominated action." 19 Thus civil society can influence government in two ways: "It enhances political responsiveness by aggregating and expressing the wishes of the public through a wealth of nongovernmental forms of association; and it safeguards public freedom by limiting the government's ability to impose arbitrary rule by force." 20

Three concepts, "civility," "democracy," and "contention," seemed especially central to either one or both of these literatures. We developed them into a set of questions that can be asked both of specific international nongovernmental advocacy initiatives in education and of the nature of collective efforts and interrelationships as a whole:

1. To what extent and in what ways are these initiatives building global "civility"? By "civility" we refer to the development of a dense pattern of sustained interaction and collaboration among international nongovernmental actors around a coherent framing of the issue of education. This notion draws from the ideas of Alexander de Tocqueville and Robert Putnam in focusing on the extent to which the capacity and habit of participation, reciprocity, and social pluralism is being cultivated, expanded, and sustained at an international level. ${ }^{21}$ In the transnational sphere, authors have argued that the establishment of regularized interactions between transnational actors and international organizations and nation-state governments can also be used as a measure of global civility. ${ }^{22}$

2. To what extent and in what ways are these initiatives "democratic" in the sense of representative of, and accountable to, those for whom they purport to advocate? One measure of this might be the extent to which efforts promote horizontal linkages, through new forms of communication, deci-

\footnotetext{
18 John Hall, ed. Civil Society: Theory, History, Comparison (Cambridge: Blackwell, 1995); Andrew Arato and Jean Cohen, Civil Society and Political Theory (Cambridge, Mass.: MIT Press, 1992).

${ }^{19}$ Clark, Friedman, and Hochsteltler, "Sovereign Limits of Global Civil Society" (n. 8 above), p. 3

${ }^{20}$ Ibid.

${ }^{21}$ Robert Putnam, Making Democracy Work: Civic Traditions in Modern Italy (Princeton, N.J.: Princeton University Press, 1993); Alexander de Tocqueville, Democracy in America (New York: Doubleday, 1969).

${ }^{22}$ See Clark, Friedman, and Hochsteltler, "Sovereign Limits of Global Civil Society."
} 
sion making, and direct participation, rather than new patterns of hierarchy or exclusion. ${ }^{23}$ Another measure might be the extent to which regularized structures for global (geographically representative) participation are encouraged over the reproduction of existing inequalities between citizens of rich and poor nations. The ideal of "democracy," as used in both liberal and left-liberal theories of civil society, can imply quite different ideal forms for global governance, ranging along a spectrum from radical participatory democracy to a more institutionalized form of constitutional, representative governance. ${ }^{24}$ Thus, in answering this question, it will also be interesting to ponder the kind of democracy that the practices of each advocacy initiative embodies.

3. To what extent are these initiatives "contentious" in the sense of advocating fundamental social change, independent of, or in opposition to, existing structures and initiatives organized by states and international governmental organizations? Based on the literature on social movements and Gramscian theories of civil society, one key measure of contention will be the extent to which initiatives are autonomous and provide forceful alternatives to the current structure of world order. Another measure might be the extent to which transnational initiatives have a self-reflexive strategy that targets changing global decision-making structures and supporting local level struggles. ${ }^{25}$

In asking these three sets of questions about transnational advocacy efforts in education, we do not intend to imply that they all fit neatly together. For example, the ideal of "civility" may well be at odds with the ideal of "contention," while, as noted above, democracy can take on dramatically different institutional forms. ${ }^{26}$ Nonetheless, looking at each of these questions should allow us to examine the nature, shape, and extent to which something approaching a new transnational political space, and new collective actors, are emerging around the issue of education.

${ }^{23}$ Jordan and van Tuijl; see also Johannes Galtung, True Worlds: A Transnational Perspective (New York: Free Press, 1980), and "Self-Reliance: An Overriding Strategy for Transition," in Toward a Just World Order, ed. Richard Falk, Samuel Kim, and Saul Mendlovitz (Boulder, Colo.: Westview, 1982).

${ }^{24}$ For discussion, see, e.g., Galtung, True Worlds; Richard Falk, On Humane Governance: Toward a New Global Politics (University Park: Pennsylvania State University Press, 1995); Held, Democracy and the Global $\operatorname{Order}$ (n. 6 above); Held and McGrew (n. 6 above); and Smouts (n. 14 above).

${ }^{25}$ See discussions by Robert Cox, "Social Forces, States and World Order: Beyond International Relations Theory," Millennium 10, no. 2 (1981): 126-55; Jordan and van Tuijl (n. 14 above); Lynch (n. 11 above); Claus Offe, "New Social Movements: Challenging the Boundaries of Institutional Politics," Social Research 52, no. 4 (1985): 817-69; Smith (n. 2 above); McCarthy (n. 15 above); and Tarrow, "Transnational Contention" (n. 15 above), and "Cycles of Collective Action." See also Antonio Gramsci, Selections from the Prison Notebooks: 1929-35, ed. Quintin Hoare and Geoffrey Novell Smith (London: Lawrence \& Wishart, 1971).

${ }^{26}$ As Lynch and Pasha and Blaney (n. 14 above) point out, discussions about civil society from Hegel and Gramsci onward intermarry liberal and critical ideas about the possibility of governance, notions of economic causality, and notions about economic causality and public morality. Tensions and contradictions between liberal and critical notions of international civil society are especially marked around the issue of economic globalization. 


\section{International Nongovernmental Actors and Educational Cooperation: Historical Overview}

Nongovernmental actors have long played a significant role in the field of education, beginning with the role played by religious organizations in spreading Western forms of schooling. The late nineteenth century and early twentieth century, a period that saw the rapid global spread of Western models of compulsory mass schooling, also saw the growth of secular international organizations and networks with educational interests and programs taking up such causes as child survival, children's rights, child-centered pedagogy, peace education, the need for internationalism among youth and students of higher education, and teachers' rights. ${ }^{27}$

There is very limited research on these organizations-certainly too little to allow us fully to assess their roles in spreading Western educational models or in pushing for greater intergovernmental cooperation in the field of education. Nonetheless, our survey of secondary sources suggests that the evolution of formal intergovernmental organization in education during the twentieth century owed much to periods of intense nongovernmental activism, especially at key historical conjunctures when new institutions for international cooperation were being formed. ${ }^{28}$ After World War I, for example, it was primarily nongovernmental actors, including international women's organizations, international teachers' unions, and transnational groups of progressive educators, who pushed the League of Nations toward the formation of an International Institute for Intellectual Cooperation, despite the hesitation of member governments. ${ }^{29}$ Some of the same nongovernmental actors helped to create the International Bureau of Education, which later became the first intergovernmental body focused on the problems of public education. Nongovernmental organizations were again instrumental in the inclusion of education in the mandates of international organizations formed after World War II. In 1945, a group of predominantly Ameri-

${ }^{27}$ Hermann Rohrs and Volker Lenhart, eds., Progressive Education across the Continents (Berlin: Peter Lang, 1995); Douglas Hodgson, “The Historical Development and Internationalisation of the Children's Rights Movement," Australian Journal of Family Law 6, no. 3 (December 1992): 252-79; Institute on World Organization, World Organization: A Balance Sheet of the First Great Experiment (Washington D.C.: American Council of Public Affairs, 1942).

${ }^{28}$ Here we differ with White, who suggested in 1951 that "only a few of these [educational organizations] have done useful or important work; on the whole it must be said that the influence of private international organizations in the field of education has not been extensive. One gains the impression that their contribution has been insignificant in comparison with achievements of INGOS in the fields of business, labor, social welfare, religion, etc" (White [n. 5 above], p. 124).

${ }^{29}$ Key nongovernmental organizations advocating for formalized structures of international educational cooperation included the New Education Fellowship, the World Federation of Education Associations, the International Council of Women, and the Suffragist Conference of Allied Countries. See Adolphe Ferriere, "The New Education Movement," in Education Yearbook, 1924, ed. Isaac Kandel (New York: Columbia University, Institute for International Education, Teachers College, 1924), pp. 597-628; Rohrs and Lenhart; Pedro Rosselló, Forerunners of the International Bureau of Education, trans. Marie Butts (London: Evans Brothers, 1944); Unesco, Unesco: 50 Years for Education (Paris: Unesco, 1997), pp. 56-63; and White. Foundations also played a role: Carnegie supported the original appeal to the league, while Rockefeller provided an initial grant for the formation of the International Bureau of Education (IBE). 
can nongovernmental organizations lobbied and drafted the wording that eventually led to the inclusion of educational cooperation within the charter of the United Nations organizations. The same group of NGOs also convinced the American delegation to insist that the Economic and Social Council of the United Nations take on responsibility for the promotion of international educational cooperation, despite considerable governmental resistance. ${ }^{30}$ Later, a wide range of women's and child-welfare organizations helped to further secure the legitimacy of education as a field for intergovernmental cooperation by introducing the right to free elementary education in the 1948 Declaration of Human Rights and by urging the adoption of a separate Declaration on the Rights of the Child in 1959. In each of these instances, international nongovernmental actors overcame the hesitation of national governments, insisting that education was a legitimate, indeed morally necessary, field for international organization.

In light of these efforts, it may seem surprising that the post-World War II era, which saw an unprecedented expansion of formal intergovernmental cooperation in the field of education, did not see the development of coherent, regularized forms of networking and communication among international nongovernmental actors in the field of education. Nor did it see the emergence, until very recently, of common efforts to shape international educational institutions. ${ }^{31}$ Although the number of nongovernmental organizations with an interest in education rapidly expanded in this period, these organizations also remained highly fragmented and marginalized within what emerged as a fairly expansive arena for intergovernmental relations in education.

This marginalization can be traced to several factors, including the development of a wide array of education-related nongovernmental organizations with highly differentiated, and often isolated, mandates and interests. On the one hand, the post-1945 era saw the development of an expanding group of (mainly Northern) membership organizations, each narrowly focused on different levels of education (e.g., higher education, literacy, early childhood education, and university-level students), or specific educational issues (teacher professionalism and unionism, second-language learning, and peace education). Some of these organizations, most notably international teachers' unions, were divided into American-led or more social democratic- and Soviet-oriented organizations. ${ }^{32}$ At the same time, there was an explosion of church-based and secular charitable organizations (including a whole new generation of development and relief organizations) who

\footnotetext{
${ }^{30}$ Dorothy Robins, Experiment in Democracy: The Story of U.S. Citizen Organizations in Forging the Charter of the United Nations (New York: Parkside, 1971).

${ }^{31}$ Mundy, "Educational Multilateralism" (n. 1 above).

${ }^{32}$ Edward Thompson, "International Teachers' Organizations and Their Activities," in Teacher Unions and Associations, ed. Albert Blum (Urbana: University of Illinois Press, 1969), pp. 333-49.
} 
carried out smaller-scale educational projects in local communities, but whose work generally remained limited to supplementing national educational systems and thus concentrated in such fields as nonformal, adult, and literacy education. ${ }^{33}$ Actors across these two groups rarely came together to discuss global educational problems. Their work developed in relative isolation from each other, with only marginal linkages to the expanding work of intergovernmental organizations (like Unesco, the Organization for Economic Cooperation and Development [OECD], the World Bank, and Unicef), which had been charged in the period after 1945 with constructing education as a field for international action.

There is also considerable evidence that international nongovernmental actors saw their relationships to intergovernmental organizations become more constrained during the period 1945-80. This occurred in part because intergovernmental organizations came to view international educational problems as linked, first and foremost, to the achievement of national economic and political modernization and, thus, as primarily in need of technical expertise delivered to (and between) governments and governmental actors. ${ }^{34}$ Nongovernmental actors were quite absent in this conceptualization of educational development. Furthermore, the escalation of Cold War politics pushed intergovernmental bodies like Unesco to rigidify its relationships with nongovernmental organizations and focus more fully on governments as their chief partners. ${ }^{35}$ It is thus not surprising that nongovernmental actors ended up having highly formalized and superficial relationships with organizations like Unesco, nor is it surprising they were absent at such formative international organization (IO)-sponsored meetings on education as the 1961 OECD meeting on education and economic growth, the major regional conferences on education hosted by Unesco in the 1950s and 1960 s, the influential Bellagio conferences on education of the 1970s, and even the Unesco-sponsored literacy conferences in Tehran and Persepolis. ${ }^{36}$

\footnotetext{
${ }^{33}$ Colette Chabbott, "Defining Development: The Making of the International Development Field, 1945-90," in World Polity Formation since 1875: World Culture and International Non-governmental Organizations, ed. John Boli (Stanford, Calif.: Stanford University Press, 1999), pp. 222-48; see also the articles by Arnove, Klees, and Stromquist (n. 3 above).

${ }^{34}$ Mundy, "Educational Multilateralism"; Ramirez and Boli (n. 1 above).

35 Arthur Gillette, NGOs and Unesco: What? Why? How? The Results? (Paris: Unesco, 1968); Richard Hoggart, "Unesco and NGOs: A Memoire," in The Conscience of the World: The Influence of Nongovernmental Organizations in the United Nations System, ed. Peter Willetts, pp. 31-62 (London: Hurst, 1996); Susan Rauch, "The Quest for Universal Literacy: Who Got What from International Literacy Year, Why and How" (Ed.D. diss., University of Massachusetts, 1995); J. Thomas-Fontaine, "Collective Consultation on Literacy for All: Appraisal and Prospects" (Unesco, Paris, 1993, mimeographed). For an overview of the marginalization of nongovernmental actors within the United Nations system, see Otto (n. 14 above); Gordenker and Weiss (n. 8 above); and Willets, ed.

${ }^{36}$ Organization for Economic Cooperation and Development (OECD), "Policy Conference on Economic Growth and Investment in Education" (paper presented at the OECD Conference on Economic Growth and Investment in Education, Washington, D.C., 1961); F. Ward, ed., Education and Development Reconsidered: The Bellagio Conference Papers (New York: Praeger, 1974). The major American foundations were by and large the only visible nongovernmental participants at these events.
} 
Only in one field is there evidence that this trend toward fragmentation and marginalization was not the case: that of literacy and adult education. Here we can hypothesize that the absence of a standardized model of national responsibility left a vacuum that was quickly filled by a host of nongovernmental actors whose interest in literacy and adult education extended back to the nineteenth century. ${ }^{37}$ These NGO interests gave birth to the International Council of Adult Education and ushered in a vibrant period of transnational advocacy during the 1970s, when networks of literacy and adult education organizations were formed and engaged in highly popularized debates about the appropriate purposes and organization of education (these were led by Paulo Freire, among others). ${ }^{38}$ Yet although this new movement into educational advocacy achieved some degree of formal recognition within Unesco, the idea of alternative educational structures or of a right to adult and literacy education made little substantial headway in the programs of the new giant in the field of international cooperation in education, the World Bank, and still less in the practices of national governments. ${ }^{39}$ In the late 1980s, as sources of finance to support literacy became increasingly scarce, the cohesion of the literacy and adult education network began to erode. ${ }^{40}$

\section{A New Context of Opportunity: Education in Crisis and the Rising Involvement of International Nongovernmental Actors in the Education for All Movement}

In contrast to the period between 1950 and 1990, the second half of the 1990s has seen a remarkable explosion of international nongovernmental activity in the field of education, especially around the idea of education for all. The contextual roots of this explosion can be traced to several factors. Perhaps foremost among them, the basic assumption on which many earlier forms of nongovernmental cooperation in the field of education had been founded - the idea that education is an entitlement of citizenship, properly

${ }^{37}$ Roger Fieldhouse, The Workers Education Association: Aims and Achievements, 1903-77 (Syracuse, N.Y.: Syracuse University Press, 1977); Brian Simon, The Search for Enlightenment: The Working Class and Adult Education in the Twentieth Century (London: Lawrence \& Wishhart, 1990).

${ }^{38}$ Paulo Freire, Pedagogy of the Oppressed (New York: Herder \& Herder, 1970); Johan Galtung, "Literacy, Education and Schooling - For What?" in A Turning Point for Literacy, ed. Leon Bataille (Oxford: Pergamon, 1976), pp. 93-105; Budd Hall, "The International Council for Adult Education: Global Civil Society Structure" (University of Toronto, Ontario Institute for Studies in Education, Toronto, 1999, mimeographed); NORRAG News, no. 7, "World Conference on Education for All and International Literacy Year," in Northern Research Review and in Advisory Network on Education and Training, March 1990, ed. Kenneth King and Christine McNab (Edinburgh: Northern Research Review and Advisory Group [NORRAG], 1990), pp. 1-55; NORRAG News, no. 8, "What Happened at Jomtien?" in King and McNab, eds., pp. 1-59; Noel McGinn, ed., Crossing the Lines: Research and Policy Networks for Developing Country Education (Westport, Conn.: Praeger, 1996).

${ }^{39}$ Colette Chabbott, "Constructing Educational Development: International Development Organizations and the World Conference on Education for All” (Ph.D. diss., Stanford University, 1996); Jones, World Bank Financing of Education (n. 1 above); Leslie Limage, "Literacy Practices and Literacy Policies: Where Has Unesco Been and Where Might It Be Going?," International Journal of Education Development 19, no. 1 (January 1999): 75-90; Rauch.

${ }^{40}$ See Rauch, p. 103. 
provided by a state whose capacity as service provider was expected to expand - was steadily eroded by a worldwide economic crisis, as well as by the rise of a new set of ideas about public policy in Western welfare states. For many countries in the South, the 1980s was a lost decade in which primary enrollment rates declined and school systems fell into disarray. ${ }^{41}$ Meanwhile, in the North, questions about the ongoing capacity of governments to continue to expand both domestic social services, such as education, and international development assistance were met with an increasingly popular blend of neoconservative and hyperliberal (or neoliberal) ideas. From the mid-1980s, debates about education across countries belonging to the OECD were increasingly characterized by a new interest in such issues as privatization, public choice, decentralization, the use of national testing, and cost recovery and efficiency, each linked to this new policy agenda. Similar ideas were promulgated by the major multilateral and bilateral development organizations involved in the field of educational cooperation, especially those dominated by Western governments, the World Bank, and the OECD. ${ }^{42}$

These contextual factors alone might have been enough to stimulate new levels of activism among some international nongovernmental actors in education. But they also set in play a complex set of interorganizational dynamics that produced education as a heightened field for international debate and action. In the late 1980s, four major international organizations (Unicef, Unesco, the World Bank, and the United Nations Development Program [UNDP]) decided to host a World Conference on Education for All (WCEFA). Held in Jomtien in 1990, the WCEFA harnessed together a relatively uncoordinated group of education specialists across these agencies in an effort to expose the deterioration of worldwide access to education in the poorest of the developing countries. Its formal goal was to get governments in both the North and the South to sign on to a program of action aimed at solving this crisis. But the motivation for the WCEFA also came from the practical recognition among senior managers in Unesco, Unicef, and the World Bank that education might be an issue capable of revitalizing and legitimating their organizations in the face of mounting rich country reluctance to expand North-South development assistance. ${ }^{43}$ In turn, the WCEFA

${ }^{41}$ Fernando Reimers and L. Tiburcio, Education, Adjustment and Reconstruction: Options for Change (Paris: Unesco, 1993); Joel Samoff, ed., Coping with Crisis: Austerity, Adjustment and Human Resources (London: Cassell and Unesco, 1994); World Bank, Education in Sub Saharan Africa (Washington, D.C.: World Bank, 1988).

${ }^{42}$ Martin Carnoy, "Structural Adjustment and the Changing Face of Education," International Labor Review 134, no. 6 (1995): 653-73; Christopher Colclough and James Manor, States or Markets? Neo-Liberalism and the Development Policy Debate (Oxford: Clarendon, 1993); Keith Hinchcliff, "Neo-Liberal Prescriptions for Education Financing: Unfortunately Necessary or Inherently Desirable?" International Journal of Education Development 13, no. 2 (1993): 183-87; Mundy, "Educational Multilateralism" (n. 1 above); Henry et al. (n. 1 above).

${ }^{43}$ Among the international organizations, Unicef's director, Jim Grant, took the lead in proposing the World Conference on Education for All conference, in part because he was keen to expand its successes in child survival and saw in the promotion of basic education a way of expanding its public 
popularized the notion of a crisis in educational access at a time when a new wave of world conferences and transnational nongovernmental advocacy networks was emerging, including a network of NGOs focused on the rights of children. ${ }^{44}$ Beginning with the Rio Conference on the Environment in 1992, "education for all" (EFA) was taken up as a major theme in a series of United Nations-sponsored world conferences and summits, as well as by NGO networks on human rights, women, and child survival. ${ }^{45}$ Following Jomtien, an interagency Education for All Commission was established, with a secretariat in Unesco and a steering committee formed of representatives from intergovernmental and bilateral aid organizations. The EFA Forum, as it was called, was charged with formulating a decade of EFA activities and overseeing the realization of central WCEFA goals.

The new international interest in education for all had a complex and contradictory impact on the involvement of nongovernmental actors in the international educational cooperation arena. On the one hand, it marked the beginning of a new era of awareness and interest in nongovernmental organizations among intergovernmental organizations, which officially recognized a role for nongovernmental actors in the provision of educational services. ${ }^{46}$ In light of this recognition, a remarkable number of nongovernmental participants were invited to attend the Jomtien conference (compared with their virtual absence at earlier international meetings on educational development). Nongovernmental organizations were involved in preconference regional consultations; 125 were invited to be formal confer-

legitimacy and resource base. Unesco hoped that by joining it could rectify the fiscal and legitimacy crisis it faced after the withdrawal of the United States and Britain in the 1980s. The World Bank was also seeking new ways of legitimating and reconstituting its work in the late 1980s. It probably hoped to offset the damage caused by highly publicized transnational protests of its structural adjustment policies and convince the increasingly parsimonious OECD governments that contributions to its concessional loan fund should be expanded. See Maggie Black, Children First: The Story of Unicef, Past and Present (New York: Oxford University Press, 1996); Mundy, "Educational Multilateralism"; Chabbott, Constructing Education Development (n. 33 above); Rauch, pp. 136-38.

${ }^{44}$ Black; Hodgson (n. 27 above); Cynthia Price Cohen, "The Role of Nongovernmental Organization in the Drafting of the Rights of the Child," Human Rights Quarterly 12 (1990): 137-47.

${ }^{45}$ See declarations made at various conferences, e.g., those of the United Nations: Convention on the Rights of the Child (New York: United Nations, 1991), Agenda 21: Programme of Action for Sustainable Development: Rio Declaration on Environment and Development (Rio de Janeiro: United Nations, 1993), "World Conference on Human Rights: The Vienna Declaration and Programme of Action, June 1993," in United Nations World Conference on Human Rights (Vienna: United Nations, 1993), p. 71, "Programme of Action of the International Conference on Population and Development," in International Conference on Population and Development (Cairo: United Nations, 1994), Report of the World Summit for Social Development (Copenhagen: United Nations, 1996), and The Beijing Declaration and the Platform for Action/Fourth World Conference on Women, Beijing, September 4-15, 1995 (New York: United Nations, 1996). Another such example is OECD, Shaping the 21st Century (Paris: OECD, 1996).

${ }^{46}$ The World Declaration on Education for All (article 7) encourages the active involvement of a wide range of partners - families, teachers, communities, private enterprises, government and nongovernmental organizations. Article 7 of the declaration also notes that "great potential lies in possible joint actions with nongovernmental organizations at all levels." See Inter-agency Commission, Final Report, World Conference on Education for All (Jomtien, Thailand: United Nations Development Program, Unesco, Unicef, and World Bank, 1990). 
ence participants, and an NGO representative was invited to sit on the WCEFA steering committee. ${ }^{47}$

But while the WCEFA declaration, and the "education for all" activities that followed it, officially promoted the idea that nongovernmental actors were fundamental to the achievement of EFA, it also seems clear that the official thinking about NGO participation was focused primarily on the role of NGOs as flexible collaborators in the provision of educational services. ${ }^{48}$ This was made clear in preparations for Jomtien. Here, NGOs were given little opportunity to participate in the selection of NGO participants. Instead, sponsoring intergovernmental organizations and national delegations contended for control of invitations, with the result that some Western-based development and relief NGOs were invited, while many of the literacy and adult education NGOs officially affiliated with Unesco through its Collective Consultation on Literacy were ignored. Even though the WCEFA secretariat hosted an NGO meeting one day ahead of the WCEFA, this selection process "ensured that the NGO contingent at EFA would not, unlike many of the governmental donor organizations, form a pre-existing group." ${ }^{49}$ Many NGO delegates were critical of the WCEFA conference, comparing it with the grassroots NGO organization that preceded preparations for the Unescosponsored International Literacy Year (ILY) conference in 1990 (which Jomtien largely overshadowed). They argued that the WCEFA was dominated by an interagency agenda, was predominantly staffed by Western education development professionals (who operated with a budget 10 times larger than that provided for ILY), and embodied a Western-led set of solutions for de-

\footnotetext{
${ }^{47}$ NORRAG News, nos. 7 and 8 (n. 38 above); Angela Little and Errol Miller, A Report to the Forum's Steering Committee: An Evaluation of the International Consultative Forum on Education for All, 1990-2000 (Dakar: World Education Forum, 2000), p. 38; Interview no. 11a, representative of International Council on Adult Education representative, July 4, 1999, Toronto. Interviews for this research were undertaken by the authors between June 1999 and July 2000. They included informants from a variety of nongovernmental organizations and international organizations. Most interviews were conducted by telephone or at the organizations with which the informants were affiliated. Some interviews were also conducted at the World Education Forum in April 2000. In these notes, interviews are cited by a coded number, the affiliation of the informant, the date of the interview, and the location of the interview. Where more than one interview was conducted with the same informant, a letter (a,b, c, etc.) is added to the number.

${ }^{48}$ For related literature on the rise of NGOs as educational service providers, see Archer (n. 3 above); Stromquist (n. 3 above); Klees (n. 3 above); and Arnove (n. 3 above). An overview of the trend across service sectors can be found in Jordan and van Tuijl (n. 14 above); Alison Van Rooy, ed. (n. 14 above); and Michael Edwards and David Hulme, Beyond the Magic Bullet: Nongovernmental Performance and Accountability in the Post Cold War World (West Hartfield, Conn.: Kumarian, 1996). In a typical official statement supporting this expanded role for NGOs, a World Bank report suggests "it has become more important for residual state functions to become more efficient through the discipline of greater public accountability and for civil society (including the private sector, NGOs, and local government) to assume certain functions for which the state was previously responsible" (Bhuvan Bhatnagar and Aubrey C. Williams, cited in Rutherford, "Civil (Dis) Obedience and Social Development in the New Policy Agenda" [n. 14 above]).

${ }^{49}$ Chabbott, Constructing Educational Development (n. 39 above), p. 136.
} 
veloping country problems that emphasized a traditional North to South delivery of education that virtually ignored the issue of adult literacy. ${ }^{50}$

Jomtien follow-up activities, likewise, suggested a peripheral role for nongovernmental actors: no clear structures for NGO participation in postJomtien activities were established, and there was no NGO representative on the EFA Inter-agency Steering Commission until 1997. Unesco's Collective Consultation on Literacy (and, later, Basic Education), a NGO body that might have been expected to play a strong role vis-à-vis the new EFA secretariat at Unesco, instead remained quite marginalized in the EFA structures. ${ }^{51}$ This remained the case even after the Unesco NGO Collective Consultation became the first NGO coalition invited to appoint a representative to the interagency Education for All Steering Committee in 1997, ${ }^{52}$ in part because intergovernmental organizations provided little financial support to help the body develop the participation of its membership and, in part, because the earlier focus of its membership on literacy and nonformal education had been supplanted by the Jomtien focus on formal schooling. ${ }^{53}$ Thus, despite heroic efforts on the part of its cochairs in 1998 and 1999, the Unesco Collective Consultation proved unable to generate a common mobilizing frame or set of mobilizing strategies for nongovernmental actors in relation to the promises of education for all. ${ }^{54}$

${ }^{50}$ Rauch (n. 35 above); Hall, (n. 38 above). A classic statement of this skepticism can be found in the paper prepared by the African Association for Literacy and Adult Education (AALAE) entitled "Education for All by a Few: A Critique of the Basic Education for All Initiative, Jomtien 1990" (AALAE, Jomtien, 1990), p. 25: "Basic education for all is not achievable by the year 2000, neither is it a feasible priority ... it must be realized that it is not a lack of these skills that is threatening the survival and quality of African peoples' lives." See also NORRAG News, nos. 7 and 8 (n. 38 above); Birgit Brock-Utne, Whose Education for All? (New York: Falmer, 2000); and Interview no. 11a, representative of the International Council on Adult Education representative, July 4, 1999, Toronto.

${ }^{51}$ Interview no. 12a, cochair of the Unesco-NGO Collective Consultation on Literacy and EFA representative, July 7, 1999, High Wycombe, Buckinghamshire, United Kingdom. See also Thomas-Fontaine (n. 35 above); J. Chambon-Fountain, "Collective Consultation on Literacy for All: Appraisal and Prospects" (Unesco, Paris, 1995, mimeographed). Thomas-Fontaine provides a detailed breakdown of membership in the Unesco-NGO Collective Consultation, which has included regular participation by several large INGOS (e.g., World Education, International Council of Adult Education, and the Catholic International Education Office), one of the international teachers unions, women's INGOs, the International Union of Students, representatives from the book trade, as well as a host of smaller regional and national coalitions of literacy NGOs. Until the mid-1990s, participation in the Unesco-NGO Collective Consultation was restricted to organizations that were formally accredited with Unesco; Unesco regulations did not allow national NGOs to participate directly.

${ }^{52}$ The two cochairs of the Unesco Collective Consultation were invited to become the only NGO representatives on the 35-person EFA steering committee in 1997. See Interviews nos. 12a and 12b, cochairs of Unesco-NGO Collective Consultation on Literacy and EFA representative, July 7 and July 13, 1999, Buckinghamshire, United Kingdom.

${ }^{53}$ Historically participation in the Unesco-NGO Collective Consultation has been quite erratic and highly dependent on Unesco funding and the location of the meetings - thus, e.g., between 1984 and 1993 only about 30 NGOs participated in each annual consultation, and only 20 could be characterized as regular participants. Since 1995, wider participation has been encouraged, but funding has not increased. Rauch, p. 102; Thomas-Fontaine, p. 2. See also Unesco-NGO Collective Consultation on Literacy and Education for All, Report of the 14th Annual Meeting, 19-21 October 1998 (Paris: Unesco, 1998).

${ }^{54}$ Interview no. 16a, EFA Forum secretary, July 28, 1999, Paris; Thomas-Fontaine, pp. 12-14. Initiatives in preparation for the EFA end-of-decade review included an independent, NGO-generated 
Nonetheless, the WCEFA and its follow-up activities acted as an important catalyst for the development of new transnational linkages among nongovernmental educational actors in two ways. First, WCEFA set the stage for an expanding (though nonetheless insufficient) pool of funding for nongovernmentally implemented educational projects. ${ }^{55}$ Second, WCEFA put out a set of formal commitments among governments to which nongovernmental actors could later hold governments and international organizations accountable. Our preliminary research suggests that (at least) five important trends in nongovernmental activity emerged (or expanded) after Jomtien, each marking a considerable expansion in the education-related networking and advocacy efforts of nongovernmental organizations (see appendix).

By the mid-1990s, driven in part by the new wave of donor support and funding of nongovernmental organizations as educational service providers, a wide number of international nongovernmental organizations involved in development and relief had begun to open or expand their programs in basic education and girls' education. These are Northern based and vary considerably in the quality of their relationships to Southern nongovernmental actors-facts that have caused some authors to typify them as "venue-shoppers" who tend to focus on uncontroversial and readily programmable issues. ${ }^{56}$ Several of the largest of these organizations-including various national branches of Save the Children, World Vision, and Carelaunched educational advocacy initiatives in the 1990s. For the most part, these advocacy initiatives are not linked to the more radical demands for global governance and global transformation that have characterized the new wave of INGO activism in fields like gender, development, or debt relief. The energies of these organizations have remained by and large focused on developing their own capacities for service provision in the field of education. Their repertoires for contention focus primarily on expanding their individual representation within intergovernmental and nongovernmental organizations. They attend international conferences and adopt the broad framing of educational problems established at them, especially where these

assessment of the Education for All decade (led, as it turned out, by organizations involved in the Global Campaign) and a proposal for the development of an NGO-led "Literacy Watch" program.

55 Although WCEFA contributed to a general trend toward expanded funding of basic education among development aid donors, it never neared the $\$ 10$ billion- $\$ 25$ billion additional dollars estimated by Colclough as needed to achieve EFA by its original target date of 2000. See Paul Bennell and D. Furlong, "Has Jomtien Made Any Difference? Trends in Donor Funding for Education and Basic Education since the Late 1980s," World Development 26, no. 1, (1998); and Christopher Colclough and Keith Lewin, Educating All the Children (Oxford: Clarendon, 1993).

${ }^{56}$ Gordenker and Weiss, "NGO Participation in the International Policy Process" (n. 8 above); Ian Smillie, "Act Globally: The Rise of the Transnational NGO," in The Alms Bazaar: Altruism under Fire-Non-profit Organizations and International Development (London: Intermediate Technology, 1995), pp. 197-213. 
frame the problem of education for all within the notion of children's rights. ${ }^{57}$

A second new trend can be seen in the expansion of education-related activities among a new breed of "virtual transnationals," coalitions of development NGOs utilizing new telecommunications technologies to build a common front for lobbying governments and the broader public about global governance issues. ${ }^{58}$ In the late 1990 s, education became a prime theme in the advocacy work of these networks. Two examples are illustrative here. "Reality of Aid" is an initiative, first launched by the International Council on Voluntary Action and Eurostep in 1993, which is aimed at providing independent reports on official development aid. In 1997, 1998, and 1999 , its reports focused on donor performance in basic education. Similarly, SocialWatch, an initiative sponsored by a broad coalition of Southern NGOs, has published reports that draw attention to governmental commitments to basic education made at the WCEFA and the World Summit for Social Development. ${ }^{59}$ These virtual transnationals model a new repertoire for contention in the field of nongovernmental activism in education, bringing nongovernmental actors together in sophisticated information gathering and "watchdog" efforts.

Perhaps the most striking response to the WCEFA, however, has been a movement toward highly contentious campaigning and coalition building among nongovernmental actors in the field of education. In fall 1999, three nongovernmental actors launched independent advocacy campaigns that targeted the education for all commitment made by governments and international organizations at Jomtien. Two of these, Oxfam and ActionAid, are large, multibranched Northern development NGOs with successful policies of fostering Southern nongovernmental organizational partnerships and ex-

\footnotetext{
${ }^{57}$ Interview no. 3a, representative of Save the Children (United States), June 28, 1999, Westport, Conn.; Interview no. 3b, representative of Save the Children (United States), April 27, 2000, Dakar, Senegal. The Save the Children family of organizations is a good illustration of this trend. Members of the International Save the Children Alliance attend international educational conferences, participate in the international children's rights campaign, and recently developed an International Working Group on Basic Education. For the most part, however, this family of organizations is more focused on establishing a baseline of good educational practices than on international advocacy that links educational needs to issues of globalization or economic injustice. International Save the Children Alliance, "Save the Children Position for the World Education Forum" (International Save the Children Alliance, London, 2000). Also see CARE, "About CARE, Profile," 2000 (http://www.care.org/about/index.html, August 7,1999 ).

${ }^{58}$ Examples here would include organizations like the Canadian Council for International Cooperation (CCIC), Eurostep, Civicus, and the International Council on Voluntary Action (ICVA), as well as a number of predominantly Southern NGO coalitions, such as the Third World Network and SocialWatch. The CCIC is a coalition of Canadian development NGOs, while Eurostep is a European NGO coalition; ICVA and Civicus are both global NGO coalitions. See their web sites: CCIC (http://www.fly.wet.net/ ccic), Eurostep (http://www.oneworld.org/eurostep/), ICVA (http://www.icva.ch/), Civicus (http:// www.civicus.org), and SocialWatch (http://www.socwatch.org.uy). The term "virtual transnational" is used by Smillie in The Alms Bazaar (n. 56 above).

${ }^{59}$ Social Watch, Social Watch, No. 3 (Montevideo: Instituto del Tercer Mundo-Social Watch, 1999).
} 
perience in developing highly publicized campaigns for fundraising in the North. The third campaign was launched by Education International, an international association of teachers' unions formed in 1993. In 1999, these organizations joined their campaigns to launch a Global Campaign for Education, targeting both the end-of-decade review of Jomtien education for all efforts, the UN follow-up conference of the Social Summit, and the spring meetings of the Group of Seven (G7).

Because these campaign and coalition building initiatives so closely imitate transnational advocacy efforts in other fields, we think it is worth looking more closely at the development of their mobilizing frames and repertoires of contention. We do so below before turning to examine the efforts of Global Campaigners and other nongovernmental actors at the culminating event of the Education for All decade, the World Education Forum held in Dakar, Senegal, in April 2000.

\section{The Genesis and Evolution of the Global Campaign for Education: Oxfam's "Education Now" Global Action Campaign}

The organization that has played the leading role in forging the Global Campaign for Education is Oxfam International. Established 53 years ago as a relief NGO in Britain, Oxfam has grown into a "transnational" development NGO. ${ }^{60}$ It has autonomous national chapters in 11 countries. These affiliates carry out activities in over 120 countries and have a combined budget of approximately US\$390 million. ${ }^{61}$ Unlike many of the other superNGOs, much of Oxfam's budget comes from nongovernmental sources. ${ }^{62}$

In 1995, convinced that processes of globalization required Oxfam to augment its influence and involvement in an emerging global political arena, the federation of Oxfams created Oxfam International, a network organization designed to increase Oxfam's influence on donor and Southern governments and international organizations, especially on such issues as debt relief, International Monetary Fund (IMF) structural adjustment programs, and intergovernmental commitments to development assistance and global social welfare. ${ }^{63}$ Discussion within Oxfam International turned to the idea of

\footnotetext{
${ }^{60}$ Gordenker and Weiss; Smillie.

${ }^{61}$ Oxfam International, "Oxfam International: Why Oxfams Work Together," n.d. (http://www .oxfam.org/about/why.htm, July 29, 1999).

${ }^{62}$ See Maggie Black, Cause for Our Time: Oxfam, the First Fifty Years (New York: Oxford University Press, 1992); Oxfam America, "Frequently Asked Questions," 1998 (http://www.oxfamamerica.org/ FAQ.html, May 17, 1999); Oxfam International, "Annual Report,” 1997 (http://www.oxfam.org/ a_report/03advoc.htm, May 17, 1999). Oxfam also raises funds through gift sales and gets resources from bilateral development agencies. Unlike other super-INGOs, however, Oxfam's operating budget is not primarily derived from the subcontracting of foreign aid projects. Some Oxfam groups, like Oxfam America, do not receive any funding from government sources.

${ }^{63}$ See Community Aid Abroad, "A New Era of International Advocacy-Oxfam International,” 1995 (http://www.caa.org.au/horizons/h12/forsyth.html, August 4, 1999). When asked in an interview about the main aims of Oxfam International, its head Justin Forsythe noted, "the primary aim of the office is to achieve changes to the policies of the IMF, the World Bank, and the United Nations. It will do this through
} 
launching a global campaign in 1997, when the organization felt a need to revitalize its debt and structural adjustment campaigns. Despite the fact that the federated Oxfams have relatively little experience in the field of education, education was chosen as the campaign theme for two key reasons. First, there existed multiple recent international declarations and commitments regarding education for all and a clear pattern of backsliding on these commitments among donors. ${ }^{64}$ Second, "education for all" seemed capable of bringing home the reality of the debt crisis and the emergent problems of globalization to the average citizen. ${ }^{65}$

The federated Oxfams launched their joint campaign "Education Now" in March 1999. Initially, the campaign appeared squarely focused on establishing Oxfam's own agenda vis-à-vis international organizations, the public, and the interagency EFA network. Oxfam sought, and received, the endorsement of one of Britain's largest newspapers, the Guardian. ${ }^{66}$ It approached both the World Bank and Unicef with a global action plan in December 1998, proposing that they adopt the Global Action Plan as the financial mechanism for meeting EFA goals. The Global Action Plan called for specific financial commitments for meeting the Jomtien Education for All targets; the establishment of an independent facility for delivering resources to education debt relief for impoverished countries; reform of the IMF, World Bank, and other intergovernmental organizations whose policies have impeded spending on basic education and other social services; increases in levels of bilateral foreign aid; and the use of debt relief and policy reforms to encourage Southern governments to spend more on education.

In both the Global Action Plan and the "Education Now" report, Oxfam developed a distinctive mobilizing frame for thinking about global access to education. Rather than tackling such questions as Why education and not food security? (a debate common in bilateral aid organizations), What kind

\footnotetext{
building relations with the key institutions we hope to influence, helping develop strategies, lobbying, providing information to the different Oxfams to inform their advocacy work, and facilitating contact for our partners from the south" (ibid.). Also see Oxfam International's preparatory materials for the Social Summit in 1995, where they argued that "any new institutional framework needs to address the fact that the globalization of the economy has shifted the burden of protecting peoples rights away from national governments and towards private actors, such as transnational organizations" (quoted in Lynch [n. 11 above], p. 170).

${ }^{64}$ Interview no. 4a, representative of Oxfam International, March 20, 1999, Washington, D.C.; Interview 5a, representative of Oxfam Canada, April 14, 1999, Toronto; Interview 6a, representative of Oxfam America, June 29,1999, Boston; Interview 8a, representative of Oxfam United Kingdom, June 14, 1999, Oxford; Interview 10a, representative of Oxfam United Kingdom, July 7, 1999, Oxford. As expressed by one Oxfam informant, "with the many radical statements and promises governments have made to provide education, it was seen as a good issue to plan a campaign around, and with the end of the decade, century, and millennium, there is mounting pressure to do something big and important to work towards poverty alleviation" (Interview no. 7a, representative of Oxfam United Kingdom, June 18, 1999, Oxford).

${ }^{65}$ See Oxfam International, Oxfam International: Why Oxfams Work Together.

${ }^{66}$ Guardian Weekly, "Inside the News: Resources: Education Now! Education Is the Most Important Factor in Development. Ian Hunt Examines Oxfam's New Report” (March, 23, 1999), p. 10.
} 
of education, education for what? (the key question raised by the international literacy and adult education movement), or How best to deliver education services? (a common preoccupation among reform-minded educationists as well as neoliberal public policy analysts), Oxfam used the issue of access to education to illustrate the more general failures of international organizations and governments in the North and the South to provide basic public goods. To quote from Oxfam's Education Now: "Various polite formulations can be found to explain away the collective failure of governments. But the hard fact is that the rights of the world's children are being violated by the world's governments - the same governments that have reneged on the promises made at Jomtien." ${ }^{67}$ Oxfam also made a clear statement that education must be free and properly delivered by the state-both issues that were sidestepped in the final declaration of the Jomtien conference. ${ }^{68}$

The early impact of Oxfam's campaign launch was impressive. Oxfam was quickly invited to join the interagency committee overseeing post-Jomtien efforts, as an NGO representative on the EFA steering committee. ${ }^{69}$ Media coverage of the campaign was also significant. However, by summer 1999, Oxfam's call for a Global Action Plan had been modified by the steering committee, whose members ruled out the idea of a special funding facility for education. ${ }^{70}$

Two other components of the Oxfam International campaign strategy in 1999 are worth noting. The first is Oxfam's efforts to link the Education Now campaign to the Jubilee 2000 debt relief campaign and the broader network of INGO and social movement organizations opposing structural adjustment and neoliberal macroeconomic policies. ${ }^{71}$ At the July 1999 Group of 8 (G8) summit, Oxfam joined with Education International to conduct a high-level

${ }^{67}$ Oxfam International, Education Now (Oxford: Oxfam International, 1999), p. 2.

${ }^{68}$ Indeed, the current UN special rapporteur on human rights and education argues that the framing of education in the WCEFA declaration actually derogates on these points from earlier conventions in which education was recognized as a human right. See Katerina Tomasevski, "Economic and Social Rights: Preliminary Report of the Special Rapporteur on the Right to Education," Fifty-Fifth Session of the ECOSAC Commission on Human Rights (United Nations Economic and Social Council, E/CN.4/ 1999/4, New York, January 13, 1999).

${ }^{69}$ Interview no. 6a, representative of Oxfam America, June 29, 1999, Boston; Interview no. 9a, representative of Oxfam United Kingdom and former member of EFA Steering Committee, June 30, 1999, Oxford. See also EFA Forum, "What's New at the Education for All Forum: Education International's Appeal to the Heads of State and Governments of the G8, June 19-20," 1999 (http://www.unesco.org/ education/efa/newsjune1999/eig8.htm, June 29, 1999).

70 The global action plan was still intended to lay out the financial mechanisms for how EFA goals could be met, but representatives from the World Bank, Unicef, and Unesco became involved in revising the plan. One Unicef official remarked, "the IGOs will continue to build on the GAP but how we see that it will work and by our rules" (Interview no. 13a, representative of Unicef, July 1, 1999, New York). Interview no. 16a, EFA Forum secretary, July 28, 1999, Paris; Interview no. 12c, representative of Unesco-NGO Collective Consultation, July 20, 1999 in Buckinghamshire, United Kingdom; Interview no. 14a, representative of World Bank, July 13, 1999, Washington, D.C. See also the "EFA Bulletin 1999," on the Unesco/ EFA web site at http://www.unesco.org/education/efa/efa_36/analysis.htm.

${ }^{71}$ See reference to Jubilee 2000 Coalition (n. 9 above). 
lobbying campaign, and it also participated in the Jubilee 2000 direct action. One outcome of this lobbying was a statement by the G7 and G8 ministers promising a new debt relief initiative that placed considerable emphasis on access to education; the G7 ministers also promised to include civil society in the preparation and implementation of World Bank and IMF projects. Education International later joined Oxfam in meetings with the heads of the IMF and the World Bank. ${ }^{72}$

Oxfam International also launched efforts to engage its national chapters in local advocacy around the Education Now campaign. This proved somewhat problematic, however, because Oxfam affiliates often have a limited background in education and few links to other educational actors. ${ }^{73}$ Oxfam sought to overcome this handicap by developing a broader coalition of nongovernmental actors involved in education at the international level.

Education International: A New International Advocacy Effort among Teachers Unions

By the middle of 1999, Education International, the recently formed international association of teachers trade unions, emerged as Oxfam's chief partner in global educational advocacy. It later became the coordinator and headquarter organization for the Global Campaign for Education. Education International's participation marks two novel events in the field of nongovernmental activism in education. First, it suggests a renewed solidarity and internationalism among teachers unions, which have for decades been sharply divided into rival international associations. ${ }^{74}$ Second, it marks the beginning of a new era of cooperation between international trade union associations and other international nongovernmental actors around a common agenda for global change. ${ }^{75}$ For both these reasons, it is impor-

${ }^{72}$ Group of 8 (G8) Summit, "G8 Communiqué Köln, 1999” (http://www.g8cologne.de, June 23, 1999, Cologne, Germany); Jubilee 2000 Coalition, "Jubilee 2000: Details and Interpretations of the Koln Debt Initiative," June 23, 1999 (http://www.jubilee2000uk.org/news/kolndebt.html, June 29, 1999); Unicef/Oxfam International, "Policy Paper, Debt Relief and Poverty Reduction: Meeting the Challenge," August 1999 (http://www.oxfam.org/advocacy/papers/debtchallenge.htm, August 23, 1999). For a description of the Jubilee 2000 campaign, see n. 9 above. For the Group of 8 summit, Oxfam ran a joint advertisement with Education International (Education Now, no. 3 [London: Actionaid, 1999, available at www.elimu.org]); Interview no. 10a, representative of Oxfam United Kingdom, July 7, 1999, Oxford.

${ }^{73}$ Interviews nos. 5a and 5b, representative of Oxfam Canada, interviewed April 4 and May 5, 1999, Toronto; Interview 6a, representative of Oxfam America, June 29, 1999 in Boston; Interview 7a, representative of Oxfam United Kingdom, June 18, 1999, Oxford; Interview 8a, representative of Oxfam United Kingdom, June 24, 1999, Oxford. Most of Oxfam's national chapters did host media and public education events and lobby government officials concerning the need to follow through on their Jomtien commitments to support education for all.

${ }^{74}$ Education International, Congress Highlights: Speeches from the Constituent Congress of Education International, ed. Nick Patrice and Vezina Grieswood (Morges, Switzerland: Education International, 1993), p. 35; Thompson (n. 32 above).

${ }^{75}$ Indicative of this, the WCOTP, one of Education International's predecessor organizations, is described by Thomas-Fontaine (n. 35 above) as having "never taken part (except very briefly from 198485 ) in the work of the [Unesco Collective NGO] Consultation, owing to internal crisis, on the one hand, and, on the other, the difficulty of broadening the scope of literacy problems beyond teachers concerns" (p. 5). 
tant to consider the mobilizing frames and repertoires for contention that Education International brings to the new educational advocacy.

In 1993, 97 percent of the members of the International Federation of Free Teachers Unions and the World Confederation of Organizations of the Teaching Profession agreed to a merger of the two organizations, ending decades of fierce rivalry and ideological disagreement. ${ }^{76}$ The new association, Education International, is "a world-wide trade union organization of education personnel" that is committed to both the expansion of trade unionism among teachers and the development of a unified, professional vision of global educational issues. ${ }^{77}$ Education International has 23 million individual members, drawn from 294 national trade unions and associations in 152 countries and territories. It is governed by policy resolutions made at triennial World Congresses, and it has an elected executive board. Its activities are implemented by a secretariat based in Brussels and through six regional offices. ${ }^{78}$

Historically, the central concern of international teachers associations has been the establishment of international standards on the status of teachers. ${ }^{79}$ This concern has continued to be a major focus for the activities of Education International, but the new organization has also reorganized its aims and goals around the threat to teachers, and to public education more generally, posed by austerity and the new policy agenda. Education International's new mobilizing frame is captured well in the address of Fred Van Leeuwen, the organization's general secretary, at Education International's founding congress. He promised that Education International would wage a battle with neoliberalism, step up efforts to influence the IMF and the World Bank, and target the "international education crisis. . . . [as marked] by austerity measures in the South and by neo-liberal schemes in the North, put forth to destroy free compulsory education and replace it with some form of fragmented semi-public or private system." ${ }^{80}$ Van Leeuwen concluded, "Let there be no misunderstandings about our intentions to use this organization as a tool to intensify the North-South dialogue, to help establish a more just international economic order, to pursue the active involvement of trade

\footnotetext{
${ }^{76}$ Education International, Congress Highlights, p. 35.

77 These and other quotations, where not cited, are drawn from the Education International web site at http://www.ei-ie.org/main/english/index.html. See also its two periodical publications, Education International Magazine and the Monitor.

78 Regional offices include one in Africa (Lome, Togo); two in Asia/Pacific (Kuala Lumpur, Fiji); and one each in Latin America (Costa Rica), North America (Washington, D.C.), and the Caribbean (St. Lucia). The Brussels secretariat has five departments: education, trade union and human rights, development cooperation, information, and administration. According to its web site, the three main focuses of Education International activities since its formation in 1993 are the (1) right to quality public education for all, (2) the protection of international standards of human and trade union rights, and (3) the improvement of the status of women.

${ }^{79}$ For a full history, see Education International, "The Recommendation on the Status of Teachers," at http:/ / www.ei-e.org/educ/english/eed1966rec.htm.

${ }^{80}$ Education International, Congress Highlights.
} 
unions, and to reform the significant role that public education plays in democratic development, economic growth and social progress." 81

Thus, alongside its more traditional advocacy of the right of teachers to collective bargaining, Education International, like Oxfam, has become engaged in broader debates about economic globalization. Indicative of this, it has expanded its activities to include research and lobbying related to the World Trade Organization. ${ }^{82}$ Education International is also active in the defense of children's rights and the promotion of human rights more generally (especially as related to discrimination against women, racism, homophobia, promotion of the rights of indigenous peoples, and child labor) ${ }^{83}$ It has played an active role in the child labor movement and is a founding member and international convener of the Global March against Child Labor, the fourth INGO to join the Global Campaign on Education.

Early in 1999, Education International officially launched a campaign calling for "Quality Public Education for All" after it was given the mandate to do so by resolution of its 1998 World Congress. The ideological centerpiece of its mobilizing frame is an unequivocal commitment to the notion of publicly funded and provided free education. In the view of Education International, public education is a necessary safeguard against the growth of economic and social inequality. Education International argues that public education (as compared with privatized education) is also more likely to encompass a humanistic, plural, and democratically oriented curriculum. The Education International campaign has also argued for the right of teachers (and other civil society actors) to participate in national and international educational policy-making arenas. Here Education International builds on such earlier efforts as its 1994 report on the inclusion of teachers in the Education for All initiatives of the nine most populous countries. ${ }^{84}$ Finally, the Education International campaign takes up specific policy issues related

${ }^{81}$ Fred Van Leeuwen, quoted in ibid., p. 30.

${ }^{82}$ Education International argues that the WTO-sponsored liberalization of trade in educational services will threaten public education, and it also wants to see the WTO create a working group on international labor standards. See Education International, "The WTO and the Millennium Round: What Is at Stake for Public Education?" in Questions for Debate, no. 2 (Brussels: Education International, May 1999, http://www.ei-ie.org/educ/english/eedQD3_june99.html), and "After Seattle: Vigilance Is Necessary," December 15, 1999 (http://www.ei-ie.org/action/english/Globalisation/etrseattle.htm).

${ }^{83}$ See, e.g., resolutions on these issues made at the first (1995) and second (1998) Education International World Congresses. These resolutions can be found on the Educational International web site (http://www.ei-ie.org/main/english/index.html), respectively, at http://www.ei-ie.org/edu/english/ eeires95index.html and http://www.ei-ie.org/edu/english/eeires98index.html. See also the annual publication, Education International, Barometer on Trade Union and Human Rights in the Education Sector, 1998 (Brussels, Education International, July 1998). Child Labor is the focus for one of the three campaigns Education International is currently conducting. A 1995 resolution of the World Congress mandates Education International to hold regional meetings among indigenous educators and commits the organization to the promotion of indigenous peoples' rights.

${ }^{84}$ See Education International, "Education for All," Questions for Debate, no. 3, (Brussels: Education International, June 1999, available at www.ei-ie.org/main/english/index.html), "Quality Public Education for All," Education International Quarterly Magazine (Brussels: Education International, October 1999), and Defending Teacher Union Rights (Brussels: Education International, 1994). 
to what it describes as the neoliberal policy agenda in education: it questions existing approaches to national standardized testing, decentralization, privatization, and civil service reform. Each of these issues is taken up in the newsletters and journals Education International circulates to its membership, and in research and policy documents it posts on its popular web site.

Education International's decision to help launch the Global Campaign for Education in fall 1999 brought to new nongovernmental advocacy in education both a distinctive mobilizing frame and a new and extensive repertoire for contention. Although Education International's capacity to mobilize its membership has not yet been tested, the organization represents the largest membership-based international nongovernmental actor with an interest in educational issues. It also boasts extensive formal affiliations to other international union movements and formal consultative status with many United Nations organizations. Its status as a trade union movement suggests a capacity for disciplined and coherent activism. ${ }^{85}$

ActionAid, the Global March against Child Labor, and the Launching of the Global Campaign

During 1999, two other organizations and several Southern NGO networks joined with Oxfam and Education International to launch the Global Campaign. The most distinctive and active in shaping the Campaign platform was ActionAid, a British NGO, which is not only among the largest U.K. development NGOs, but also a member of a family of NGOs with affiliates in Ireland, France, Italy, and Greece. ActionAid emphasizes community development and partnership with Southern NGOs and citizens organizations; since 1990, it has engaged in advocacy work, with current campaigns on the issues of education for all, ending the sex trade, and the threat to ThirdWorld agriculture posed by genetically engineered seeds. ${ }^{86}$ Unlike Oxfam, ActionAid has worked extensively in the field of education in developing countries, and it is well known for its development of community-based methods for teaching adult literacy and for its early involvement in such nonformal and nongovernmental educational initiatives as the Bangledesh Rural Action Committee (BRAC).$^{87}$

Not only was ActionAid an early partner in the Global Campaign but it also launched its own distinctive education campaign, "Elimu: Education for Life," in 1999. The Elimu campaign is focused on building the capacities of

${ }^{85}$ Education International ascribes to the general policies of the International Confederation of Free Trade Unions and works especially closely with the Public Service International. It also holds category 1, NGO consultative status, with Unesco, the International Labor Organization (ILO), the IBE, the World Bank, the OECD, and the Economic and Social Committee of the United Nations.

${ }^{86}$ Interview nos. $17 \mathrm{a}$ and $17 \mathrm{~b}$, representative of ActionAid, Reality of Aid project, and Global Campaign for Education Steering Committee, respectively, July 28, 1999, and January 31, 2000, London; see also ActionAid's web site at http:/ / www.actionaid.org.

${ }^{87}$ See Archer (n. 3 above). Action Aid is also cross-networked: it was a lead agency in the Reality of Aid project and is a lead agency in Unesco's Collective Consultation. 
local NGOs and civil society organizations to participate in national education policies. It operates as a coalition of national campaigns and regional networks in the South, producing its own newsletter and giving rise to many opportunities for South-South collaboration. Its objective is to "increase the participation of poor people in the design and implementation of education policy and practice by organizing people around education issues, forming strong alliance with civil society and influencing governments and donors." 88

Global March against Child Labor, a Southern-based coalition of NGOs that views itself as the world's largest social movement in defense of exploited children, also joined the leadership of the Global Campaign in 1999. ${ }^{89}$ Launched in 1997, the Global March was initially organized around a highly publicized series of national demonstrations and a worldwide march in which both national policies and international agreements related to child labor were the lobbying target. The campaign appears to have played an important role in getting governments to agree to the development of the new international Convention on the Worst Forms of Child Labor. The Global March coalition placed education high on its agenda, going so far as to argue that free education is "the best way of ending child labor." 90

Both ActionAid's Elimu campaign and the Global March Coalition brought to the Global Campaign for Education a unique opportunity for partnership with a large number of Southern NGOs. Several Southern coalitions subsequently joined the campaign, some of which include the South African NGO Coalition; the Campaign for Popular Education (Bangladesh); the Brazilian National Campaign for the Right to Education; the Citizen's Education Initiative in India; the Ghana National Education Campaign Coalition; the Civil Society Action Committee on EFA, Nigeria; Association du Sahel d'Aide à la Femme et à l'Enfance, Mali; Cadre de Concertation en Basic Education, Burkina Faso; Consultation of Adult Education in Latin

${ }^{88}$ The Elimu campaign documents and statements can be found at http://www.elimu.org/ issue.htm. Some of these coalitions, such as Tanzania, Ghana, Burkina Faso, Mali, Bangladesh, India, Brazil, and Senegal, have already launched an education campaign (Education Now, no. 3 [n. 72 above]; Actionaid, Elimu Update: July 2000 [London: Actionaid United Kingdom, 1999 and 2000]; Interview no. 8a, representative of Oxfam United Kingdom and current cochair of Global Campaign for Education, June 24, 1999, Oxford; Interviews nos. 17a and 17b, representative of ActionAid, Reality of Aid project, and Global Campaign for Education Steering Committee, July 28, 1999, and January 31, 2000, London).

${ }^{89}$ The mission of the Global March is "to mobilize world-wide efforts to protect and promote the rights of all children, especially the rights to receive a free, meaningful education and to be free from economic exploitation and from performing any work that is likely to be damaging to the child's physical, mental, spiritual, moral and social development" (cited from the Global March web site at www.globalmarch.org/about_the_march/index.html). Among its originators were NOVIB (Oxfam in the Netherlands) in conjunction with Anti-slavery International, the International Labor Rights Fund, ChristianAid, Casa Alianza, ECPAT (End Child Prostitution, Pornography, and Trafficking), Fundação Abrinq, Education International, Network against Child Labor, and the South Asia Coalition on Child Servitude. See documentation provided at http://www.globalmarch.org.

${ }^{90}$ See Global March web site at http:/ /www.globalmarch.org. 
America, Mexico; Forum for African Women Educationalists, Mozambique; and Tanzania Education Network. ${ }^{91}$ The campaign's eight-person steering committee reflects this widening membership: four positions are held by representatives of ActionAid, Oxfam, Education International, and the Global March against Child Labor. The other four are held by four Southern NGO coalitions, including a representative from CAMPE, Bangladesh; Education International, Togo; the Brazilian National Campaign for the Right to Education; and the South African National NGO Coalition.

With these new partners, the Global Campaign for Education promised to mobilize "public pressure on governments to fulfil their promises to provide free, quality education for all people, in particular for our children and for women." 92 Each of the campaign's sponsoring organizations continued to develop its own independent campaign, while joining in a series of joint efforts leading up to the Dakar world forum. These included a "millennium appeal" letter sent to heads of states calling for high-level participation in the EFA review and commitment to the goal of education for all; and a "Global Week of Action" in April 2000 to engage NGOs and teachers unions around the world in advocacy activities the week prior to the Dakar meeting. ${ }^{93}$ Campaigners also joined Unesco in hosting an NGO parallel conference at the Africa regional EFA preconference meetings in 1999. By March 2000, the campaign claimed the affiliation of over 400 nongovernmental members.

Overall, the campaigners' preparations for the Dakar meeting suggested a new kind of coherence and mobilization among nongovernmental actors in the field of education. In November 1999, they began a heated and contentious exchange with the intergovernmental agencies sponsoring the EFA review. Campaign sponsors sent a strongly worded letter to World Bank president James Wolfensohn signaling their intention to make the Dakar forum a key event in their campaign. The letter described the interagency EFA forum as "failing to galvanize governments and build a constituency around the EFA project," and it demanded "evidence of a concrete global plan of action through which the resources needed to achieve the goal of education for all can be mobilized; and through which civil society and local communities are given a greater voice in the development of education policies." 94 In

${ }^{91}$ See Actionaid, Elimu Update: Winter 1999 (London: Actionaid United Kingdom, 1999). For a complete list of organizations who have joined the campaign, see Global Campaign for Education, "Organizations Active in the Global Campaign for Education, Listed per Country," March 29, 2000 (http:// www.campaignforeducation.org/who_is/who_is.html, May 1, 2000).

${ }^{92}$ See the mission statement "What Is the Global Campaign?" (http://www.campaignfor education.org/what is/what_is.html, n.d.).

${ }^{93}$ Education International, "Quality Education for All-Make It Happen Now! The Global Action Week: A Resounding Success! Press Release," March 2000 (http://www.ei-ie.org/main/english/ index.html, May 1, 2000).

${ }^{94}$ Letter from James D. Wolfensohn, president of World Bank, October 20, 1999 (http:// www.ei_ie.org/main/english/index.html, December 15, 1999). 
TABLE 1

Global Campaign on Education: Partners, Repertoires, and Mobilizing Frames

\begin{tabular}{|c|c|c|}
\hline & Core Mobilizing Frame & Strategic Repertoires \\
\hline \multicolumn{3}{|l|}{ Education for All: } \\
\hline Official Frame & $\begin{array}{l}\text { Education is a basic right and a re- } \\
\text { quirement for national develop- } \\
\text { ment. It depends on national polit- } \\
\text { ical will and better "partnerships." }\end{array}$ & $\begin{array}{l}\text { - Global declarations: persuade develop- } \\
\text { ing country governments to sign on to } \\
\text { the goal of education for all. } \\
\text { - Shift educational aid to target basic } \\
\text { education. } \\
\text { - Provide better technical solutions } \\
\text { and more careful data for monitoring } \\
\text { progress. }\end{array}$ \\
\hline \multirow{2}{*}{$\begin{array}{l}\text { Oxfam Interna- } \\
\text { tional: Educa- } \\
\text { tion Now }\end{array}$} & & \\
\hline & $\begin{array}{l}\text { The achievement of the right to } \\
\text { education depends on debt relief, } \\
\text { reform of international organiza- } \\
\text { tions, and a clear commitment by } \\
\text { governments to the provision of } \\
\text { free, quality public education to all. }\end{array}$ & $\begin{array}{l}\text { - Use aggressive popular media cam- } \\
\text { paign and high-level lobbying to ex- } \\
\text { pose failure of Western governments } \\
\text { to meet their Jomtien commitments. } \\
\text { - Link efforts to other campaigns for } \\
\text { debt relief (Jubilee 2000). Form broad } \\
\text { coalition of nongovernmental organi- } \\
\text { zations (NGOs) and international non- } \\
\text { governmental organizations (INGOs). } \\
\text { - Focus on lack of resources at global } \\
\text { level. }\end{array}$ \\
\hline \multicolumn{3}{|l|}{$\begin{array}{l}\text { Education Inter- } \\
\text { national: Qual- } \\
\text { ity Public Edu- }\end{array}$} \\
\hline cation for All & $\begin{array}{l}\text { Quality, free, and equal publicly pro- } \\
\text { vided education for all is a global } \\
\text { priority. To achieve this goal the } \\
\text { working conditions and rights of } \\
\text { teachers must be protected and } \\
\text { teachers must become part of the } \\
\text { policy-making process, and neo- } \\
\text { liberal reforms must be fought. }\end{array}$ & $\begin{array}{l}\text { - Union-like structure with access to } \\
\text { wide geographic membership. } \\
\text { - Utilize formal links to the Interna- } \\
\text { tional Labor Organization, Unesco, } \\
\text { the United Nations, and other interna- } \\
\text { tional trade union bodies for high-level } \\
\text { lobbying. } \\
\text { - Uses language of trade unionism and } \\
\text { labor rights. }\end{array}$ \\
\hline \multicolumn{3}{|l|}{$\begin{array}{l}\text { ActionAid: Elimu } \\
\text { (Education for }\end{array}$} \\
\hline Life) & $\begin{array}{l}\text { Expand definition of public educa- } \\
\text { tion to include right to literacy and } \\
\text { adult education. Involvement of lo- } \\
\text { cal communities and NGOs in edu- } \\
\text { cational decision making is crucial. }\end{array}$ & $\begin{array}{l}\text { - Brings distinctive record in community- } \\
\text { based literacy and adult education } \\
\text { programs. } \\
\text { - Strong local NGO partnerships and } \\
\text { commitment to giving poor and mar- } \\
\text { ginalized populations a voice in na- } \\
\text { tional policy making. }\end{array}$ \\
\hline
\end{tabular}

February 2000, Oxfam (with the backing of other campaigners) announced that it would leave the EFA Forum Steering Committee in protest of its failure to organize an effective EFA effort with concrete targets and commitments, a new kind of international financial mechanism for delivering educational assistance, and a better organized and more democratic EFA secretariat. ${ }^{95}$

95 Charlotte Denny, "Oxfam Quits Campaign in Protest," The Guardian (February 10, 2000). See also Global Campaign for Education, Speech and Media Brief, April 19, 2000 (Brussels: Global Campaign for Education, 2000); for e-mail distribution list, see: mailing_list_global_edu_campaign@ei-ie.org. 
Just before the Dakar meeting, a clear, nine-point platform was adopted and widely circulated among campaign members, which they planned to use as the basis for lobbying at the Dakar declaration (see table 1) ${ }^{96}$ Press conferences were held in Tokyo and Washington, D.C. ${ }^{97}$ Meetings with members of national delegations and other important actors such as the European Union were held. ${ }^{98}$ Throughout the week before the Dakar conference, electronic messages were shared among Global Campaign participants as they tried to identify which high-level leaders would be attending Dakar and which delegations would meet with them in Dakar. All of these efforts took place in the face of the relative disorganization of the World Forum organizers, who both attempted to keep a tight limit on NGO invitations to Dakar and failed to establish explicit procedures or mechanisms for the amendment of the Dakar declaration. ${ }^{99}$

\section{The New Educational Advocacy in Action: The World Education Forum, April 2000}

What kind of interim assessment can we offer of these admittedly relatively new trends toward coalition building, advocacy, and contention in the field of international educational cooperation? One way of answering this question is to look more closely at nongovernmental activism at the Dakar 2000 World Education Forum, the most recent in a long line of international meetings held to discuss global educational problems and the culminating meeting of the United Nations Education for All decade. In what follows, we do not claim to provide an exhaustive account of the outcomes of the Dakar meetings. Rather we follow in the footsteps of other scholars who have attempted to understand the issue of transnational advocacy and global civil society by focusing on the changing nature of nongovernmental participa-

\footnotetext{
${ }^{96}$ See Global Campaign for Education, The Global Action Plan for Education (Brussels: Global Campaign for Education/Education International, 2000), p. 5, The World Education Forum in Dakar, Success or Failure? Our Bottom Line Position (Brussels: Global Campaign for Education/Education International, 2000), p. 6, and "Global Campaign on Education, Mission Statement and Common Purpose," October 1999 (http://www-ei-ie.org/camp/english/efa/GlobalCamp/eed_missionstat.htm., April 1, 2000).

${ }^{97}$ Education International/Global Campaign for Education, "Symposium on the Educational Situation in G8 Countries: Tokyo," April 4, 2000 (http://www.ei-ie.org/ressourc/speeches/gce tokoyo_40400.htm, April 20, 2000); Education International/Global Campaign for Education, "Transcript of the Washington Press Conference: Global Campaign to Get Every Child in the World into School," April 3, 2000 (http://www.ei-ie.org/ressourc/speeches/er_spe_gcewash_030400.htm., April20, 2000).

${ }^{98}$ For example, Oxfam Great Britain, ActionAid, and a host of other British NGOs, including Save the Children Fund/UK, made a (failed) bid to get Tony Blair to come to Dakar and take a stand on EFA similar to that taken by the United Kingdom in the Highly Indebted Poor Country (HIPC) initiative. See Guardian Weekly, "Blair Declines to Lead Fight for Education” (April 3, 2000), p. 2; and Guardian Weekly, "Blair's March on Downing Street" (April 21, 2000), p. 10. See also Global Campaign for Education, "European Union Position," April 18, 2000 (Global Campaign for Education, 2000); e-mail distribution list at: mailing_list_global_edu_campaign@ei-ie.org.

${ }^{99}$ See, e.g., "More on DFID" on the Global Campaign for Education e-mail distribution list available at: mailing_list_global_edu_campaign@ei-ie.org,April 19, 2000.
} 
tion at international conferences. ${ }^{100}$ Much of what we report here is drawn from our own experience of participating in and observing the Dakar forum, as well as from the interviews we conducted while at the conference.

The Dakar meeting was somewhat different from the Jomtien conference, where nongovernmental actors participated alongside other delegates and where only a small, Unesco-hosted NGO preconference was held. Dakar was also much smaller in scale than the major UN conferences of the 1990s, with fewer than 800 issued invitations and no formal United Nations oversight. ${ }^{101}$ Members of the conference's interagency steering committee hoped to channel NGO participation into regional preparatory conferences, and thus they kept tight control over a highly limited number of invitations to the World Forum. These were primarily given to national delegations. As a result, nongovernmental participants formally invited to participate in the World Education Forum numbered only 55 (as compared with 125 NGOs represented at Jomtien, 3,000 at the 1995 Beijing World Conference on Women, and 248 at the 1993 Vienna Conference on Human Rights). Less than 300 invitations were issued to the Dakar NGO preconference (as compared with approximately 300,000 attenders who flooded Beijing and the 598 NGOs who officially attended the Vienna preconference). ${ }^{102}$ The World Education Forum was, nonetheless, similar to many other UN conferences in that it included both an officially sponsored preconference for nongovernmental actors (something that had not happened at Jomtien) and a series of drafting and roundtable meetings intended to produce a new framework for action as well as a set of intergovernmental commitments on the theme of "education for all." 103

Nongovernmental actors-both those belonging to the Global Campaign and others - took their participation in Dakar very seriously, and they

\footnotetext{
${ }^{100}$ Clark, Friedman, and Hochstelter, "Sovereign Limits of Global Civil Society" (n. 8 above); Van Rooy "Frontiers of Influence" (n. 8 above); and Gordenker and Weiss, "NGO Participation in the International Policy Process" (n. 8 above). See also Gordenker and Weiss, "Pluralizing Global Governance: Analytical Approaches and Dimensions," Third World Quarterly 16, no. 3 (1995): 357-89; and Anne Marie Clark, Elisabeth Friedman, and Kathryn Hochstetler, "Sovereignty, Global Civil Society, and the Social Conferences: NGOs and States at the UN Conferences on Population, Social Development, and Human Settlements" (paper presented at the International Studies Association, Washington, D.C., February 1620, 1999), p. 19.

${ }^{101}$ Private communication, EFA Steering Committee Member, February 5, 2000, and April 30, 2000. Ultimately, an estimated 1,500 persons attended the closed forum. See World Education Forum (WEF), Provisional List of Participants (Dakar: World Education Forum, 2000).

${ }^{102}$ Clark, Friedman, and Hochstelter, "Sovereign Limits of Global Civil Society." See n. 45 for a list of conference declarations.

${ }^{103}$ Clark, Friedman, and Hochstelter ("Sovereign Limits of Global Civil Society," p. 8) note that "All UN world conferences share similar goals and format. A central focus of official business at each conference and its preparatory meetings is the creation of a final conference document to be endorsed by state participants. At regional preparatory meetings, governments develop regional positions on specific conference issues. The additional meetings of the Preparatory Commission . . f focus on drafting the conference document. The wording of the final document is invariably the focus of intense politicking among state and between NGOs and states."
} 
used the event as an occasion to develop their advocacy networks, as well as their repertoires for contention. Dakar, therefore, provides an important opportunity to consider the nature and extent of the "civility," "democracy," and "contention" exhibited in the new educational advocacy efforts among nongovernmental organizations.

\section{Civility}

Both the character of nongovernmental participation at Dakar and the kinds of nongovernmental activism leading up to it suggest a growing density of transnational nongovernmental activities around the theme of "education for all," indicative of the kind of civility that Anne Marie Clark, Elisabeth Friedman, and Kathryn Hochsteltler describe in their account of NGO activism at other major United Nations Conferences during the 1990s. ${ }^{104}$ The Dakar conference saw the participation of a slightly larger number of nongovernmental actors than did the WCEFA in 1989. Continuing the shift begun at Jomtien, large development and relief organizations, as well as a few nonprofit consulting groups, held a disproportionate number of invitations, while members of literacy and adult education groups participated in smaller numbers and with less coherence. ${ }^{105}$

But the real change between the two conferences can primarily be found in the development of a highly cohesive strategy for coordination among nongovernmental participants. Focused primarily around the leadership of the Global Campaign for Education, nongovernmental actors held preconference strategy sessions, met daily for debriefings, huddled around the campaign's media table, argued over the content of their formal report to the World Education Forum, and held meetings to elect nongovernmental representatives to the two key committees formed for the conference, the Declaration Drafting Committee and the Futures Committee. ${ }^{106}$ Even though many points of disagreement between campaigners and noncampaigners emerged, the nine-point "Bottom Line" platform prepared by the Global Campaigners became the recognized mobilizing frame for intra-NGO dis-

104 Ibid.

105 World Education Forum (WEF), "List of NGO Participants" (Paris: International Consultative Forum of NGOs, March 2000), Provisional List of Participants, and "Newsletter of the World Education Forum in Dakar, No. 2" (Dakar: International Consultation Forum on Education, 2000). On the opening day of the conference, Southern NGOs waited most of the day for their registration forms to be processed because the communication that NGOs were invited to register and participate had not reach the registration desk until midday. Meanwhile, several Northern NGOs who were officially invited entered along with the rest of the official delegates. In contrast, the Jomtien conference only had two large development NGOs present, World Vision and the International Save the Children Alliance. See Inter-agency Commission (n. 46 above). At Dakar, these INGOs also attended, but there was a new participation by more radical INGOs, such as Oxfam and ActionAid.

${ }^{106}$ Interview no. 23a, representative of ActionAid, May 4, 2000, London. Each of these events was also attended and observed by one of the authors. The efforts made by the International Consultation of NGOs and the Unesco Collective Consultation of NGOs to coordinate a nongovernmental platform before and during the NGO preconference were overshadowed throughout the week by the efforts of $\mathrm{Ox}$ fam, ActionAid, and Education International. The week's events were also listed on the Global Campaign for Education web site at http:/ /www.campaignforeducation.org, June 5, 2000. 
cussions and for general lobbying efforts. ${ }^{107}$ The coherence of the campaign's mobilizing frame is suggested in the fact that Global Campaign members were elected for the large majority of NGO seats on the Drafting and Futures Committees. ${ }^{108}$ Among the NGOs participating in the campaign, Dakar saw a high degree of frame alignment and the development of widely shared understandings about the "rules of the game," each suggestive of a widening civility. ${ }^{109}$

New levels and kinds of civility among international nongovernmental actors, governments, and intergovernmental organizations emerged at Dakar. Initial efforts to limit the numbers of nongovernmental organizations attending the preconference and the formal proceedings of the World Education Forum were ultimately reversed in a last-minute decision by the Unesco director general on the eve of the first day of the forum. ${ }^{110}$ At the forum itself, nongovernmental actors were also integrated in various ways into the conference proceedings: they read a statement of their demands at the opening of the forum, addressed several of the plenary sessions, elected a total of 10 representatives to the Steering and Futures Committees, and had a plenary and strategy session devoted to the sole issue of future EFA participation with civil society. Southern NGOs were invited to special meetings with national delegates from Britain and the Netherlands. ${ }^{111}$ Speeches

${ }^{107}$ See Global Campaign for Education, World Education Forum in Dakar, Success or Failure? (n. 96 above), p. 6. See also Global Campaign for Education, The Global Action Plan for Education (n. 96 above). In our observations we noted that even noncampaigners used the nine points and the Global Action Plan idea in lobbying efforts. Moreover, the NGO declaration prepared for the WEF bore a strong resemblance to the platform of the Global Campaign. See International Consultation of NGOs, NGO Declaration on Education for All (Dakar: International Consultation on Education for All, 2000), p. 4.

108 The drafting committee had four NGO representatives, which included a representative from the Global March against Child Labor, the Brazilian National Campaign for the Right to Education, Oxfam United Kingdom, and the Council of Non-governmental Organizations in Support of Government (CONGAD), Senegal. All four representatives are members of the Global Campaign, and two serve on its steering committee. The futures group had six NGO representatives, from ActionAid, Acuo Educativa (the parent organization of the Brazilian National Campaign for the Right to Education), Education International, the Arab Resource Collective, the Civil Society Action Committee on EFA, and the Asian-South Pacific Bureau of Adult Education. Of these 10 representatives, eight are members of the Global Campaign for Education. No representative from the Unesco NGO Collective Consultation was elected to either body.

${ }^{109}$ It is important to note, however, that some NGOs found the campaigners distinctly "uncivilized." For example, one representative of a larger, Northern-based development organization with a long history of work in education told us: "Here [at Dakar] we're seeing the ugly side of NGOs. They are screaming and pushing their way into things. . . . For us, advocacy comes from our demonstrated experience" (Interview no. 3b, Save the Children [United States] representative, April 27, 2000, Dakar, Senegal).

${ }^{110}$ Originally 55 NGOs were invited to send a single delegate each to the World Forum. This was in keeping with the EFA Steering Committee's objective of limiting and keeping tight control over attendance at the conference. About 150 nongovernmental participants ultimately attended the WEF. Our interviews with Southern NGOs and teachers' unions revealed that many others had hoped to attend the WEF but had not done so after being denied an official invitation to the conference (Interview no. 25a, representative of Brazilian Education Network, April 24, 2000, Dakar, Senegal). Like them, we were denied official permission to attend or observe the conference by the Unesco EFA secretariat.

${ }^{111}$ Interview no. 23a, representative of ActionAid, May 4, 2000, London; Interview no. 17c, representative of ActionAid, May 5, 2000, London; Interview no. 24a, representative of Oxfam International, May 5, 2000; Interview no. 22a, representative of Citizen's Initiative on Education India, April 30, 2000, Dakar, Senegal. 
by officials from intergovernmental organizations and governments formally endorsed the Global Campaign and recognized a new role for what was commonly referred to as "civil society" in achieving education for all. ${ }^{12}$ Official recognition of the Global Campaign was carried further when several highlevel officials held individual meetings with the campaigners. ${ }^{113}$ The character of this civility, however, varied. Among intergovernmental bodies, for example, the World Bank showed the strongest interest in working with campaigners. ${ }^{114}$ Unesco, on the other hand, did not formally endorse the campaign or hold a separate meeting with the campaigners, at least partly because its EFA secretariat was criticized by many of the participating nongovernmental organizations. ${ }^{115}$

All of these factors suggest a more formalized recognition of nongovernmental actors at Dakar than at Jomtien, a new acceptance of their role as policy-level interlocutors, and new degrees of coordination and coalition building among NGOs themselves. Of course this new civility was not "complete," and below we discuss some of the rivalries and uncivil behavior which did occur. Potential threats to the campaign's contributions to global civility can be seen in competition among campaign sponsors and the possibility of serious disputes over their various visions of education. For example, there would seem to be a likely tension between ActionAid's emphasis on local community control of education and the assumption by Education International and its teachers unions that educational decision making is properly concentrated at the national level. But there are also signs that the patterns of civility initiated by the campaign at Dakar are continuing to widen: in early May the popular web site Oneworld.net launched a new portal to cover Education for All, and the Global Campaign has also launched a web site and listserve for all civil society actors interested in supporting the campaign. ${ }^{116}$

${ }^{112}$ See World Education Forum, WEF, News and Views-Speeches-Carol Bellamy: Plenary Address by Unicef, April 27, 2000 (http://www2.unesco.org/wef/en-news/coverage_speech_belamy.shtm, May 2, 2000); World Education Forum, "WEF, News and Views, Online Coverage, Speeches: A Time for Action: Placing Education at the Core of Development," by James D. Wolfensohn, president, the World Bank, April 27, 2000 (http://www2.unesco.org/wef/en_news/coverage_speech_wolfen.shtm., May 1, 2000), "UN Secretary General, Address to the World Education Forum: Building a Partnership for Girls' Education," (Dakar: World Education Forum, 2000), and "Address by Mark Malloch Brown, Administrator of the UNDP to the World Education Forum" (Dakar: World Education Forum, 2000). These speeches and other press releases are available at the World Education Forum web site (http:/ / www2.unesco.org/wef/ en-news / latest.shtm), June 5, 2000.

${ }^{113}$ Interview no. 17c, representative of ActionAid, May 5, 2000, London; Interview no. 24a, representative of Oxfam International, May 5, 2000, Washington, D.C. Some of these meetings were also attended by one of us.

${ }^{114}$ Oxfam has played a leading role in lobbying the World Bank, which has more sustained contact with the campaigners than any other international organization (Interview no. 9b, representative of Oxfam United Kingdom and former member of EFA Steering Committee, April 23, 2000, Washington, D.C.; Interview no. 24a, representative of Oxfam International, May 5, 2000, Washington, D.C.).

${ }^{115}$ Camilla Crosa-Silva and Kailash Sathyarti, "What We Achieved at Dakar," Elimu Update (London: July 2000), p. 1 .

116 The Global Campaign has its own web site at http://www.campaignforeducation.org on which one can join an active list-serve in which information about campaign plans and events are shared. 
Democracy

How democratic, that is, representative and accountable, was the participation and activism of nongovernmental actors at Dakar? Perhaps what is most interesting here is that these questions were among the most frequently raised issues at nongovernmental meetings during the Dakar conference, as well as in our individual interviews with Dakar participants. In Dakar, both nongovernmental participants and some officials were quick to criticize the dominant role played by the Global Campaign at the conference, pointing out in particular that the campaign is led by a few Northern-based organizations, several with limited experience in the field of education and with less than altruistic motives. ${ }^{17}$ Some Southern NGO participants, as well as members of the Global Campaign itself, questioned whether this dominance had led to too great a campaign focus on Northern governments and international organizations at the expense of building self-sufficient Southern coalitions. ${ }^{118}$ Reflecting this, Southern organizations voiced less satisfaction than others about the accomplishments of the campaigners at Dakar, because these did not include serious targets for Southern government expenditure on education. ${ }^{119}$ Leaders from Save the Children Alliance, Care, and World Vision (the first two of which belong to a sizeable number of nongovernmental actors that were not affiliated with the campaigners at Dakar) faulted the campaign's overemphasis on resource mobilization and its narrow definition of schooling. ${ }^{120}$ Others regretted the loss of real discussion about education-

Oneworld.net, a popular portal for news about the Third World, international development, and new social movements, is sponsored by about 685 organizations, mainly nongovernmental. Its page on education allows readers to send letters to members of the World Education Forum Drafting Committee, join Oxfam's Education Now campaign, and to join the Global Campaign for Education e-mail list-serve. The Oneworld.net page can be found at http://www.oneworld.net/campaigns/education/index.html.

${ }^{117}$ Unesco representatives in particular raised this question; some NGO informants interviewed felt that Unesco had kept too tight a control over NGO participation and had tried to demonize the Global Campaign as an attempt by Oxfam to control international funds (Interviews nos. 17b and 17c, representative of ActionAid, January 31, 2000, and May 5, 2000, both in London). Frustrations with the limited invitations to the preconference were aired publicly at the open house the Global Campaign held on the eve of the preconference.

118 This issue was also discussed openly at several of the NGO meetings and in private communication among the authors and the campaign members throughout the week. It is a point of contention between Oxfam and ActionAid, with ActionAid demanding more attention to the development of national networks and regional coalitions in the South. The campaign steering committee addressed these tensions in their last meeting in Dakar, where both Northern and Southern partners expressed the need for the campaign to focus on building Southern coalitions.

119 Global Campaign for Education, "Final Press Release and Speech by Tom Bediako," April 28, 2000, with distribution list (May 8, 2000). In a debriefing meeting held at the end of the week for the NGOs, the achievements throughout the week were discussed. Individuals from Northern NGOs expressed that while they did not achieve all that they had hoped to, they were organized, highly visible, and able to influence parts of the framework. As one Southern NGO representative present at the debriefing expressed, "I am not so quick to pat myself on the back before I go. ... We are leaving without real commitments from governments and donors to finance basic education."

${ }^{120}$ Among the NGOs we identified as not affiliating with the campaign at Dakar are: Save the Children (United States), Save the Children (the Netherlands), the Unesco Collective Consultation and several of its members such as the Summer Institute for Linguistics, the Asia-South Pacific Bureau of Adult Education, and the International Council on Adult Education, CARE, and Plan International. 
specific matters and criticized the campaigners for importing a slick lobbying machinery into the EFA process.

Attention to the question of democracy was also carried through to the final meetings among the Global Campaigners, the group that became, at least in official eyes, the de facto representative of civil society. For example, tensions emerged between campaigners who preferred more fluid approaches to representation versus those who preferred the more formal, centralized, and hierarchical model of organizing used by Education International (which has a union-like membership structure). At one point, a rift opened up between Oxfam and other campaigners when Oxfam endorsed the World Bank's "fast track plan" for EFA on behalf of the campaign without consulting other members. ${ }^{121}$ ActionAid and Southern affiliates argued for greater attention to the inclusion of Southern actors and for the mobilization of Southern networks. Campaign leaders appeared to take these debates seriously, announcing that they would include more Southern representatives on the campaign steering committee and would make the mobilization of regional and national NGO networks a key part of future activities. ${ }^{122}$

One of the major constraints to democracy and accountability among nongovernmental actors at Dakar was rooted in the official structure of the conference itself. Dakar followed a common UN model for international meetings that is structured around the goal of achieving consensus among governmental delegations and that is only gradually developing a common approach to the integration of nongovernmental actors in the process. At Dakar, this model was evidenced in efforts to control NGO invitations and in the absence of transparent and preestablished processes for amending the declaration. ${ }^{123}$ The official intergovernmental community provided no direct funding for NGO participation, and official organizers felt very limited responsibility for ensuring that a wide, or representative, sample of NGOs participated. In this context, what happened at Dakar is not surprising: the loudest voices among the nongovernmental participants became recognized as the common voice for civil society at the conference.

The very fact that the issue of NGO participation was so openly debated might be seen as an indication that a certain criterion of democratic practice

${ }^{121}$ The World Bank's fast-track proposal focuses on offering quick disbursing money for education to governments that have acceptable national education plans. See World Bank, "Draft Proposal World Bank for Consideration for Inclusion in the Framework for Action" (Dakar: World Bank, 2000); World Education Forum, WEF Press Releases: A Time for Action, Placing Education at the Core of Development, April 27, 2000 (http://www2.unesco.org/wef/en-press/relea_dak_0427_18h.shtm., May 1, 2000).

${ }^{122}$ Interview no. 17c, representative of ActionĀid, May 5, 2000, London; Interview no. 23a, representative of Actionaid, May 4, 2000, London; Interview no. 24a, representative of Oxfam International, May 5, 2000, Washington, D.C.

${ }^{123}$ Interview no. 20a, prior secretary of Inter-agency Commission, April 27, 2000, Dakar, Senegal; Interview no. 23a, representative of ActionAid, May 4, 2000, London. One NGO representative we interviewed (personal communication, April 25, 2000) explained that the invitation process for him was quite extensive, including a written statement of the desired goals and objectives for the forum and an extensive phone call with one of the conveners. 
was achieved at Dakar. However, the overall pattern of relationships among NGOs at Dakar tended to mimic the structure of center-periphery relations in the world system, in which Northern actors play leadership and coordination roles. Furthermore, NGO criticisms of the EFA structure and their efforts to formalize their role in future EFA activities seem to have been sidetracked. According to the July 2000 newsletter of ActionAid's Elimu Campaign, "no concrete alterative to existing EFA structures was agreed . . Unesco Director General Matsuura made a change to the Framework after it had been adopted by the plenary, giving a negative message as to Unesco's intentions to become more transparent and accountable. . . . No explicit steps were proposed to increase coordination and cooperation by the international community." 124

Ultimately the test of democracy lies in the realization of NGO commitments to collaborate with a broader range of partners and to engage Southern and smaller NGOs in educational advocacy. Even if this should occur, however, careful empirical study will be needed to ascertain whether a greater representation of ideas from the grassroots occurs. Increased levels of interaction might also cause rising levels of disagreement and competition in ways that will test the formal commitment to "democratizing" relationships among actors, or it could produce a top-down socialization of new and weaker partners in which authentic participation is lost. ${ }^{25}$

\section{Contention}

How far has the development of new international nongovernmental activity in the field of education gone toward meeting the idealized criteria of contention? One way of answering this question is to consider the extent to which these new initiatives - both in their mobilizing frames and in their repertoires of contention - promote fundamental social change and alternative visions of world order that are in opposition to, or independent of, existing structures and activities organized by states and intergovernmental organizations. More concretely, we can try to weigh the success of their contention by looking at the effects nongovernmental advocacy appears to have had on the decisions made at Dakar.

Campaigners brought a clear platform of demands to the Dakar conference. As can be seen in table 2, at least some of their demands were met: inclusion of the wording "free" education; endorsement of the idea of national educational forums and an expanded definition of education that includes commitment to early childhood education and adult literacy; and a commitment to annual high-level EFA review meetings. Perhaps not so surprisingly, the campaigners did not wield sufficient influence to achieve commitments on issues that cut more closely into the prerogatives of existing

\footnotetext{
${ }^{124}$ Crosa-Silva and Sathyarti (n. 115 above).

${ }^{125}$ For discussion, see Boli and Thomas" (n. 2 above), pp. 3-6.
} 
TABLE 2

Demands Made by the Global Campaign and Their Effects on the Dakar Declaration

\begin{tabular}{|c|c|}
\hline Mobilizing Frame & Effect on Final Declaration \\
\hline $\begin{array}{l}\text { Clear, time-bound commitments by governments } \\
\text { and international organizations (IGOs) to pro- } \\
\text { viding free and compulsory basic education }\end{array}$ & $\begin{array}{l}\text { Change from affordable education to free and } \\
\text { compulsory education by } 2015 \text { in final text. } \\
\text { However, there is no mention of sanctions for } \\
\text { countries that do not meet goals and targets. }\end{array}$ \\
\hline $\begin{array}{l}\text { Clear and time-bound process for countries to } \\
\text { agree to their own plans of action for achieving } \\
\text { education for all (EFA), with binding mecha- } \\
\text { nisms for civil society participation }\end{array}$ & $\begin{array}{l}\text { National plans to be developed with civil society } \\
\text { by } 2002 \text {. Plans will "be time-bound and action- } \\
\text { oriented." Commitment to building National } \\
\text { EFA Forums, with mandatory civil society en- } \\
\text { gagement. }\end{array}$ \\
\hline $\begin{array}{l}\text { Clearer and measurable commitment to an ex- } \\
\text { panded vision of basic education - especially } \\
\text { in quality, gender equity, literacy, and non- } \\
\text { formal education }\end{array}$ & $\begin{array}{l}\text { National plans to address six goals of Education } \\
\text { for All with } 50 \% \text { improvement in adult literacy } \\
\text { by } 2015 \text {, commitment to early childhood edu- } \\
\text { cation, and gender equity }\end{array}$ \\
\hline $\begin{array}{l}\text { A clear international financial commitment to } \\
\text { EFA, both through binding commitments from } \\
\text { governments and through a financial Global } \\
\text { Action Plan with a special provision for sub- } \\
\text { Saharan Africa. The suggested target is } 8 \% \text { of } \\
\text { all bilateral aid earmarked for basic education. }\end{array}$ & $\begin{array}{l}\text { The final document mentions a "global initiative } \\
\text { aimed at developing strategies and mobilizing } \\
\text { resources needed." Several donors (Canada, } \\
\text { the United States, and the World Bank) an- } \\
\text { nounced unilateral funding increases, but do } \\
\text { not earmark a specific percentage. }\end{array}$ \\
\hline A new code of conduct to improve aid itself & $\begin{array}{l}\text { The framework makes references to improving } \\
\text { donor coordination, strengthening sector-wide } \\
\text { approaches, and providing debt relief and/or } \\
\text { cancellation. Sub-Sahara Africa is named as one } \\
\text { of neediest areas. }\end{array}$ \\
\hline $\begin{array}{l}\text { "Democratization, decentralization, and empow- } \\
\text { erment of the present Education for All struc- } \\
\text { tures and mechanisms." Campaigners seek to } \\
\text { "empower" future EFA mechanisms with civil } \\
\text { society participation, and call for the reform } \\
\text { of Unesco in particular. }\end{array}$ & $\begin{array}{l}\text { Unesco reinstated as lead in EFA (wording to } \\
\text { reform and strengthen Unesco was omitted by } \\
\text { its director general without consultation of the } \\
\text { futures' committee); also a new commitment to } \\
\text { the development of national EFA forums with } \\
\text { civil society participation. }\end{array}$ \\
\hline $\begin{array}{l}\text { A commitment to a mid-term global review of EFA } \\
\text { in } 2006 \text { and an official United Nations confer- } \\
\text { ence in } 2010\end{array}$ & $\begin{array}{l}\text { Framework calls for an annual review, led by D.G. } \\
\text { of Unesco and made up of high-level officials to } \\
\text { hold the global community accountable for } \\
\text { commitments made in Dakar. }\end{array}$ \\
\hline
\end{tabular}

Sources._Global Campaign for Education, The Global Action Plan for Education (Brussels: Global Campaign for Education and Education International, 2000), and The World Education Forum in Dakar, Success or Failure? Our Bottom Line Position (Brussels: Global Campaign for Education and Education International, 2000), p. 6. World Education Forum-Dakar Senegal, Outcomes and Next Steps, 2000 (http:// www.elimu.org/newstest1.html, May 5, 2000); World Education Forum, The Dakar Framework for Action, Education for All: Meeting our Collective Commitments, Revised Final Draft (Dakar: World Education Forum, 2000), 5, and "WEF Press Releases: 181 Governments Adopt Framework for Action at the World Education Forum," April 28, 2000 (http://www2.unesco.org/en-press/relea_dak_0428_1940.shtm, May 1, 2000).

international organizations or nation-states, especially those of the more powerful donor states. Thus, demands for a clear commitment of resources by rich country governments were again sidestepped (as they had been at Jomtien). No minimum investment targets were set by governments or the international community. Wording related to the necessary reform and strengthening of Unesco was removed. The key innovation proposed by the 
campaigners in their Global Action Plan - the establishment of a new international funding mechanism for education development under joint IO, government, and civil society oversight - was also left aside, in part because rich country governments prefer to deliver resources bilaterally, on a countryby-country basis. ${ }^{126}$

On the other hand, several things about the repertoires of contention utilized by NGOs participating in the Global Campaign for Education suggest that this was a more deeply contentious form of nongovernmental participation than has previously been seen in the international educational arena. Strategically, the campaigners were better and more professionally organized, they utilized high-level technologies to support the sharing of information, and they did, indeed, mobilize a wide coalition of nongovernmental and civil society actors. Thus, Education International argues that "the difference between Jomtien and Dakar is not in the final declaration. Hundreds of thousands of activists, teachers and parents have made governments and world institutions sit up and listen. We will not go away until every child is in school and adult illiteracy is dramatically reduced. That is the difference." 127

Some aspects of the mobilizing frame of the campaign were also effectively contentious. As we have noted earlier, the campaigners have distinguished themselves from other nongovernmental participants at Dakar by embedding the problem of education within a larger agenda for changing North-South, center-periphery relations and by taking the view that education can be used as a venue for enlarging national and transnational civic action. The campaigners clearly view their efforts against the backdrop of a much larger wave of transnational advocacy efforts that urge the development of what Michael Edwards et al. call "new social contracts" between citizens and authorities at various levels of the world. ${ }^{128}$ The Global Campaigners thus link the crisis of basic education to problems of economic globalization, debt relief, structural adjustment, and declining aid from G7 nations, and they make demands for free, publicly provided, mass education and an expanded voice for nongovernmental organizations, unions, and peoples organizations in domestic educational policy-making arenas. The impact of this mobilizing frame on the Dakar Framework for Action is evident in its stronger recognition of the right to free (not just "affordable") education, in the direct attention paid to the responsibilities of the state and

\footnotetext{
${ }^{126}$ Education International, "Campaigners Say 'Don't Let Dakar Repeat the Decade of Failure,'” April 28, 2000 (http://www.ei-ie.org/main/english/index.html, May 1, 2000); Global Campaign for Education, "Final Press Release and Speech by Tom Bediako" (n. 119 above). Clare Short, the U.K. minister for development cooperation was adamant on this point (see Guardian Weekly, "World Summit Clash on Education of Poor" (April 26, 2000), p. 2

${ }^{127}$ Elie Jouen, of Education International, as quoted in Global Campaign for Education, "Final Press Release."

${ }^{128}$ Edwards, Hulme, and Wallace, "NGOs in a Global Future" (n. 14 above), p. 2.
} 
the value of teachers, and in the official recognition of civil society's right to participate in education policy making.

Nonetheless, the choice of education as a venue for transnational advocacy raises important questions about the contention. Our case studies suggest that large INGOs went "venue shopping" in the mid-1990s and that they chose education precisely because it was an issue already adopted by governments and intergovernmental organizations and thus capable of providing them increased legitimacy and leverage. Clearly, the popularity of education as a field for international activism is conditioned by the fact that schooling is one of the most highly legitimated avenues for the provision of public welfare within Anglo-American societies and liberal political theory. In important ways, the choice of education is a reflection of the continuing hegemony of the United States within the international arena and is an indicator of the erosion of the United Nations as a forum for more politicized demands for global economic redistribution.

Being deeply contentious in this context would seem to require a fine balancing act between more general demands for greater international and national expenditure on education and a critical effort to rethink the models and purposes of schooling and its relationship to other means of ensuring social security, welfare, and solidarity on both a global and a national scale. ${ }^{129}$ Some observers believe that the Global Campaign has already done a poor job of preserving this balance-they point to its limited focus on educational matters and to its endorsement of the use of international sanctions that may further infringe upon the right of Southern countries to design their own educational plans, and they worry about the somewhat surprising bedfellow that the campaign's hard-edged approach to the achievement of EFA has found in the World Bank. ${ }^{130}$

Although such judgments are premature, they do suggest some measures of contention in educational advocacy for future research. In this category, we would also include the following questions and tensions. First, how will the campaigners deal with the tension between the fact that NGOs themselves are implicated in the new policy agenda as service providers for marginal and poor populations and their vision of an expanding, state-provided and state-guaranteed education (most forcefully advocated by Education International)? Second, will they continue to advocate for new mechanisms for

\footnotetext{
${ }^{129}$ Here it seems reasonable to echo Galtung's warning of more than 2 decades ago that a focus on schooling may lead us down the path of narrow, technical solutions to the problem of global inequality, and away from larger questions about structural inequalities and responsibilities; see Galtung, "Literacy, Education, and Schooling-For What?" (n. 38 above), True Worlds (n. 23 above), p. 150, and "Self-Reliance" (n. 23 above);

${ }^{130}$ The campaign's hard edge approach revolves around its efforts to have binding sanctions placed on governments who don't make EFA plans and meet EFA targets. Reflecting on this, a member of the steering committee noted that "things get kind of funny when you hear the World Bank talking about a soft touch and Oxfam talking about taking a hard edge" (Interview no. 21a, EFA Steering Committe member, April 27, 2000, Dakar, Senegal).
} 
channeling untied international finance for education to the developing world? ${ }^{131}$ Finally, as their framing of global educational solutions develops, will these organizations continue to push inward toward new models of learning and educational governance, as well as outward toward new forms of societal compromise and redistributive justice at a world level?

\section{Conclusion}

In this article, we have explored the emergence and evolution of nongovernmental organizational forms and actors engaged in transnational advocacy in the field of education. Our purpose was to bring a new awareness of the significance of transnational organization and the contention in world politics to existing research on the evolution of global structures influencing education. Our goals were both to describe what we suggest is a "new wave" of transnational advocacy in education and to assess its implications for the evolution of a "global civil society."

In our view, there has been an important qualitative change in the involvement of nongovernmental actors in the field of international educational cooperation over the past decade. Five key trends are suggestive of this wider development (see appendix). Development and relief organizations are becoming more interested in education, and in advocacy, and they increasingly link these two together. Virtual nongovernmental coalitions have increasingly taken up the theme of education as a component of their agendas for global governance, linking it to the issue of debt relief and to an interlocking frame of international and national responsibilities for social security and solidarity. Teachers unions around the globe have committed themselves to a renewed internationalism, and through their newly formed organ, Education International, they are launching a campaign in support of public education for all. There are clear signs of new forms of crossorganizational collaboration and of unprecedented levels of interaction between INGOs and intergovernmental bodies around the theme of education.

The heart of this article focuses on a paradigmatic instance of this new transnational advocacy in education - the genesis of a nongovernmentally sponsored Global Campaign for Education and its efforts to shape the World Education Forum held in Dakar and the future of the education for all activities of international organizations. Organizations involved in this campaign have moved into the international educational arena, not as service providers but, rather, as advocates mobilized around a well-developed action frame that links the problem of educational access to the wider issues of debt relief, human rights, and global equity and targets the erosion of national

\footnotetext{
${ }^{131}$ In the world of foreign aid, "tying" refers to the practice of stipulating that donated funds are used to purchase goods or services from the donating country.
} 
commitments to free, publicly provided educational services. To realize their demands, campaigners have employed a remarkable repertoire of strategies drawn from the experience of other transnational advocacy initiatives. They work at both international and national levels, attempting to build strong national coalitions of NGOs and civil society actors that are capable of bringing grassroots demands home to Southern governments while also generating the international support capable of altering the policies and resource allocations made to education by international organizations and the Northern governments who dominate them.

The density and coherence of these efforts is something new to the international educational arena. The Global Campaign has shown that it has much to contribute to the development of civility and democracy at the international level, and it has introduced a potentially contentious reframing of global educational needs. Should the campaign continue to develop, it promises to bring about a major reshaping of decision-making processes in the field of international educational cooperation. But the new transnational advocacy in international education is not without its limitations and tensions, which we have illustrated by considering the patterns of civility, democracy, and contention that played out between campaigners, other nongovernmental actors, governments, and intergovernmental organizations at the Dakar World Education Forum. These limits and possibilities deserve the sustained attention of scholars in the field of comparative education, offering us an opportunity to join in vital debates about new forms of collective action and societal compromise in our emergent global polity.

\section{Appendix}

Key Trends among Nongovernmental Actors in Education after 1990

1. Development and relief organizations take up or expand education sector work and move into advocacy work;

2. Virtual coalitions and advocacy networks on women, human rights, development, and debt relief take up education as a component of their agenda for global justice;

3. International teachers associations renew their commitments to internationalism;

4. Unprecedented levels of interaction emerge between nongovernmental actors and intergovernmental bodies like Unesco, Unicef, and the World Bank; and

5. New forms of cross-organizational collaboration emerge, as in the Global Campaign on Education. 